THE HYDROGEOLOGIC FRAMEWORK AND A RECONNAISSANCE OF GROUND-WATER QUALITY IN THE PIEDMONT PROVINCE OF NORTH CAROLINA, WITH A DESIGN FOR FUTURE STUDY

By Douglas A. Harned

U.S . GEOLOGICAL SURVEY

Water-Resources Investigations Report 88-4130

Raleigh, North Carolina 


\section{DEPARTMENT OF THE INTERIOR}

DONALD PAUL HODEL, Secretary

\section{U.S. GEOLOGIGAL SURVEY}

Dallas L. Peck, Director

For additional information write to:

District Chief

U.S. Geological Survey

Post Office Box 2857

Raleigh, North Carolina
Copies of this report can be purchased from:

U.S. Geological Survey Books and Open-File Reports Federal Center, Box 25425 Denver, Colorado 80225 


\section{CONTENTS}

Page

Abstract . . . . . . . . . . . . . . . . . . . . . . . . . . . 1

Introduction . . . . . . . . . . . . . . . . . . . . . . . . . . . . 2

Purpose and scope. . . . . . . . . . . . . . . . . . . . . . . 3

Method of study . . . . . . . . . . . . . . . . . . . . . . . . . 3

Acknowledgments . . . . . . . . . . . . . . . . . . . . . 4

Description of study area. . . . . . . . . . . . . . . . . . . 5

Climate . . . . . . . . . . . . . . . . . . . . . 5

Topography. . . . . . . . . . . . . . . . . . . . . . . 5

Geology . . . . . . . . . . . . . . . . . . . . . . 7

Soils. . . . . . . . . . . . . . . . . . . . . . . . 10

Land use. . . . . . . . . . . . . . . . . . . . . . . . . . . . . . 11

Hydrogeologic framework and conceptual model of the flow system. . . . 12

Regolith unsaturated zone . . . . . . . . . . . . . . . . . 12

Regolith saturated zone . . . . . . . . . . . . . . . . . . 13

Transition zone . . . . . . . . . . . . . . . . . . . . . . . . . . 17

Fractured bedrock . . . . . . . . . . . . . . . . . . . 20

Flow hypotheses. . . . . . . . . . . . . . . . . . 22

Transition zone studies... . . . . . . . . . . . . . . . . . . . 24

Potential sources of ground-water contamination. . . . . . . . . . . . . 26

Water-quality data base. . . . . . . . . . . . . . . . . . . . . . 27

Data analysis. . . . . . . . . . . . . . . . . . . . 32

Water-quality data. . . . . . . . . . . . . . . . . . 33

Independent variables . . . . . . . . . . . . . . . . . . . 33

Analysis of variance. . . . . . . . . . . . . . . . . . 36

Need for additional study. . . . . . . . . . . . . . . . . . . . . . 39

Network design. . . . . . . . . . . . . . . . . . . . . . . . 40

Data collection. . . . . . . . . . . . . . . . . . . . 43

Sampling methods. . . . . . . . . . . . . . . . . . . . . . 44

Special studies. . . . . . . . . . . . . . . . . . . . . 46

Summary and conclusions. . . . . . . . . . . . . . . . . . . . . . . . . 47

References . . . . . . . . . . . . . . . . . . . . . . 51 


\section{ILLUSTRATIONS}

Page

Figure 1. Map showing the Piedmont province of the eastern United

States and the physiographic provinces of North Carolina.

2. Sketch of conceptual structure of the Piedmont ground-water system. . . . . . . . . . . . . . . . . . . 8

3. Graph of relation of porosity of saprolite with depth. . . . 13

4. Sketch of water storage within, and the reservoir-pipeline conceptual model of the Piedmont ground-water system . . . 14

5. Graph of relation of ground-water storage and saturated thickness. . . . . . . . . . . . . . . 15

6. Graphs showing response of water-level change to rainfall. . 16

7. Hydrograph showing seasonal fluctuations in water-table depth in a well in Iredell County, North Carolina. . . . . 17

8. Topographic map showing locations of data-collection sites and topography at the Greensboro-High Point Regional Airport test site . . . . . . . . . . . . . . . . 18

9. Diagram of an idealized weathering profile through the regolith showing relative permeability . . . . . . . . . . 19

10. Sketch of six common types of fracture systems in the Piedmont. . . . . . . . . . . . . . . . . . 20

11. Block diagram showing generalized ground-water flow system in the Piedmont . . . . . . . . . . . . . . . . . . 23

12. Temperature logs for well Gu-383, June 1983 and March 1985, located at the Greensboro-High Point Regional Airport. . . 26

13. Bar graphs showing percent of ground-water contamination sources, confirmed and potential, by type, for the 251 high ranking sources in the Piedmont . . . . . . . 28

14. Map showing locations of available ground-water quality data in the Piedmont of North Carolina . . . . . . . . . . 29

15. Map showing regional ground-water investigations in the Piedmont of North Carolina . . . . . . . . . . . . . . . . 31

16. A frequency histogram for $\mathrm{pH}$. . . . . . . . . . . . . . . . 34

17. A frequency histogram for alkalinity . . . . . . . . . . . . 35

18. A frequency histogram for specific conductance . . . . . . . 35

19. A frequency histogram for dissolved-solids concentration . . 36

20. Sketch map and cross section of a hypothetical drainage basin with multiple contamination sources. . . . . . . . . 42 


\section{TABLES}

Table 1. Approximate percentages of major land uses of the Piedmont of North Carolina. . . . . . . . . . . . . . . 11

2. Summary of analysis of variance of the water-quality constituents and the four independent variables. . . . . . 38

\section{CONVERSION FACTORS}

The following factors may be used to convert the U.S. customary units published in this report to the International System of its (SI).

\begin{tabular}{|c|c|c|}
\hline Multiply & By & To obtain \\
\hline & Length & \\
\hline \multirow[t]{2}{*}{$\begin{array}{l}\text { inch (in.) } \\
\text { foot ( } f t) \\
\text { mile (mi) }\end{array}$} & $\begin{array}{l}25.4 \\
0.3048 \\
1.609\end{array}$ & $\begin{array}{l}\text { millimeter }(\mathrm{mm}) \\
\text { meter }(\mathrm{m}) \\
\text { kilometer }(\mathrm{km})\end{array}$ \\
\hline & Area & \\
\hline \multirow[t]{2}{*}{ square mile $\left(\mathrm{mi}^{2}\right)$} & 2.590 & square kilometer $\left(\mathrm{km}^{2}\right)$ \\
\hline & Velocity & \\
\hline \multirow[t]{2}{*}{$\begin{array}{l}\text { inch per hour (in./hr) } \\
\text { foot per day (ft/d) }\end{array}$} & $\begin{array}{l}25.4 \\
0.3048\end{array}$ & $\begin{array}{l}\text { millimeter per hour }(\mathrm{mm} / \mathrm{hr}) \\
\text { meter per day }(\mathrm{m} / \mathrm{d})\end{array}$ \\
\hline & Mass & \\
\hline \multirow[t]{2}{*}{ pound ( $1 b)$} & 0.4536 & kilogram (kg) \\
\hline & olume per are & \\
\hline \multirow[t]{2}{*}{ gallons per acre } & 0.009353 & $\begin{array}{c}\text { cubic meters per square } \\
\text { hectometer }\left(\mathrm{m}^{3} / \mathrm{hm}^{2}\right)\end{array}$ \\
\hline & Temperature & \\
\hline degree Fahrenheit $\left({ }^{\circ} \mathrm{F}\right)$ & $5 / 9\left({ }^{0} \mathrm{~F}-32\right)$ & degree Celsius $\left({ }^{\circ} \mathrm{C}\right)$ \\
\hline
\end{tabular}

Sea level: In this report, "sea level" refers to the National Geodetic Vertical Datum of 1929 (NGVD of 1929)--a geodetic datum derived from a general adjustment of the first-order level nets of both the United States and Canada, formerly called "Sea Level Datum of 1929." 


\title{
THE HYDROGEOLOGIC FRAMEWORK AND A RECONNAISSANCE OF GROUND-WATER QUALITY \\ IN THE PIEDMONT PROVINCE OF NORTH CAROLINA, WITH \\ A DESIGN FOR FUTURE STUDY
}

by Douglas A. Harned

\begin{abstract}
The U.S. Geological Survey is investigating the relation of groundwater quality and 1 and use in the regolith and fractured rock ground-water system of the North Carolina Piedmont. The initial phase of this study provides a description of the ground-water flow system and a review of available ground-water data and formulates hypotheses that guide the design of a water-quality monitoring network for study of selected areas.

In the Piedmont, the solid igneous and metamorphic bedrock grades upward into unweathered fractured rock that is covered by a transition zone of highly-fractured, partially weathered rock, clay-rich saprolite, and the soil. The fractured bedrock, transition zone, saprolite, and soil make up a complex flow system.

A review of available ground-water quality data shows a lack of information about organic compounds and trace metals and changes in groundwater quality with depth. Land use, soils, and geology significantly influence ground-water quality.
\end{abstract}

The hypotheses that need to be tested in the next study phase are: (1) that ground-water contamination can be related to land use, and (2) that the transition zone between bedrock and regolith serves as a primary transmitter of contaminants.

Monitoring of basins containing industrial, urban, residential, and agricultural land uses in future studies will help define the relation of ground-water quality to land use. Water quality at different depths in the flow system and in streams during base flow needs to be identified. 


\section{INTRODUCTION}

The Piedmont province of the eastern United States is one of the country's more developed and populated areas, with an ever-growing need for high-quality water supplies. Yet little is known about the ground-water system and the quality of its waters, because most major water supplies in the Piedmont have been developed from surface-water sources. Well yields in the igneous and metamorphic fractured rock system of the Piedmont are generally low compared to wells in many sedimentary rock terranes, so that use of ground water as a supply in the Piedmont generally has been restricted to individually owned domestic wells or small municipal and industrial supplies. However, in North Carolina more than half of the population in the Piedmont depends on ground water from private wells as the source for their water for domestic use (Heath and Giese, 1980).

Approximately 44 percent of streamflow in the Piedmont is ground-water discharge (Harned and Daniel, 1987). Nearly all of the baseflow in Piedmont streams is ground-water discharge. Therefore, quality of the ground water directly affects the quality of surface water.

Because most favorable surface-water sites have been developed and because concerns about environmental impacts of reservoir construction, inter-basin transfer of water, and declining surface-water quality have multiplied, interest in the use of ground water for larger supplies has been rekindled. Recent studies by Richardson (1982), Cressler and others (1983), Daniel and Sharpless (1983), and Daniel (1985) have focused on the potential of ground-water supply in the Piedmont. Other studies have stressed issues of ground-water quality management (LeGrand, 1984; Mew, 1985). However, there has been no regional study designed to assess ground-water quality in the Piedmont.

Very little is known about the nature and extent of ground-water contamination in the Piedmont province of North Carolina. Therefore, to define contamination, an understanding of the background water quality is essential. Currently, background ground-water quality data consist of analyses of major ions, with a few analyses of heavy metals and even fewer of organic compounds. 
The Toxic Waste--Ground-Water Contamination Program of the U.S. Geological Survey is conducting a series of ground-water appraisals throughout the United States (Helsel and Ragone, 1984). As part of this program, the ground-water quality of areas of widely differing geohydrology, climate, and land uses is being examined with the objective of developing a national assessment. The principal hypothesis of the program is that levels of ground-water contamination can be related to land-use. The two-phased study in North Carolina, which focuses on segments of the North Carolina Piedmont, is geared to allow transfer of information to the rest of the Piedmont province by statistically associating ground-water quality with land use, geology, and soil characteristics.

\section{Purpose and Scope}

The purpose of this report is to describe the hydrogeologic framework, present an inventory and preliminary analysis of available ground-water quality data and potential sources of ground-water contamination, and propose a design for the second phase of the study. Geohydrologic information on the region is presented, including a conceptual model of the flow system and hypotheses about contaminant movement through the system. An evaluation of available ground-water quality data is presented and a program of sampling, designed to associate land use with ground-water quality is proposed.

\section{Method of Study}

The available ground-water data that were reviewed included data collected from shallow wells between 1978 and 1980 in a program of the North Carolina Department of Natural Resources and Community Development (NRCD). The data collection effort of the NRCD study centered in the western Piedmont. The data include: (1) physical and chemical characteristics of the ground water, such as temperature, conductance, $\mathrm{pH}$, concentrations of major ionic constituents, metals concentrations, and selected analyses of nutrient concentrations; (2) 1ithologic logs; and (3) well characteristics, such as well depth and water level at time of sampling. In addition, because stream water is virtually all ground-water discharge at baseflow, data from studies that examined water-quality characteristics of streams at baseflow have been considered. A study by Eddins and Crawford (1984) 
includes low-flow sample analyses of major ionic constituents, nutrients, and metals for Mecklenburg County.

Additional data were collected specifically for the first phase of this study during January and February 1985. Samples collected in Mecklenburg and Guilford Counties were scanned for presence of organic compounds and a suite of 43 elements, including many trace metals. This information was collected to help select possible sites for detailed analysis in future study.

Historical data, collected during Geological Survey cooperative studies spanning from 1946-76, was included in the data set generated from this study. However, historical data were not used in the data analysis for this report.

The evaluation of data in this report is limited to summary presentation of certain constituents using frequency histograms, simple nonparametric analysis of variance, and Duncan multiple-range testing. A more detailed analysis of the data set is reserved for future study, which would also include additional collection of water samples from a network specifically designed to define ground-water quality.

A review of the hydrogeology of the Piedmont includes a summary of earlier work by LeGrand (1967), Heath (1984), and Daniel (1987). Temperature profile logs for several wells located in Guilford County were run to test one of the flow hypotheses of the study.

\section{Acknowledgments}

M. Groves and R. Crouch conducted the NRCD study during 1978-80 that collected much of the data that was compiled for this report. Richard Peace, of the NRCD Mooresville Regional office at the time of this study, provided access to this data.

The Climate, Topography, Geology, and Well Logs sections were written by Alexander Cardinell and Ronald Coble. 


\section{DESCRIPTION OF STUDY AREA}

The Piedmont of North Carolina (fig. 1) is part of the Piedmont province as described by Fenneman (1938) that extends from New Jersey to Alabama and lies between the Blue Ridge and Coastal Plain provinces. The Piedmont province of North Carolina, shown in figure 1 , is approximately 20,000 square miles or about 23 percent of the total Piedmont region of the eastern United States. The Piedmont widens to the south, reaching its maximum width of nearly 200 miles in North Carolina. The province occupies approximately 41 percent of the state.

\section{Climate}

The North Carolina Piedmont lies within a humid, subtropical climate region. The temperature is moderate, seldom dropping to zero degrees Fahrenheit in the winter and occasionally rising above 100 degrees in the summer. Mean annual temperatures range from 58 to 61 degrees Fahrenheit, with January the coldest and July the hottest month (Eder and others, 1983). The growing season, which is defined as that period without killing frosts, lasts from mid-April to the end of October, an average of about 200 days.

The average annual precipitation in the Piedmont of North Carolina ranges from 43 to 60 inches. Generally, the greatest monthly precipitation occurs during the summer months, and the least precipitation occurs in October or November. Although rainfall is heaviest in the summer, evaporation and transpiration losses are greatest then also; consequently, there is little ground-water recharge during this season.

\section{Topography}

The Piedmont is an ancient erosional surface developed, for the most part, on crystalline igneous and metamorphic rock. The Piedmont province is bordered on the east by the Fall Line, which is the western boundary of the Coastal Plain province, and on the west by the Blue Ridge front (fig. 1). The Fall Line represents the boundary where the soft, sedimentary rocks of the Coastal Plain give way to the harder crystalline rocks of the Piedmont. The Blue Ridge front is a prominent topographic feature generally thought to have resulted from displacement associated with faulting. 


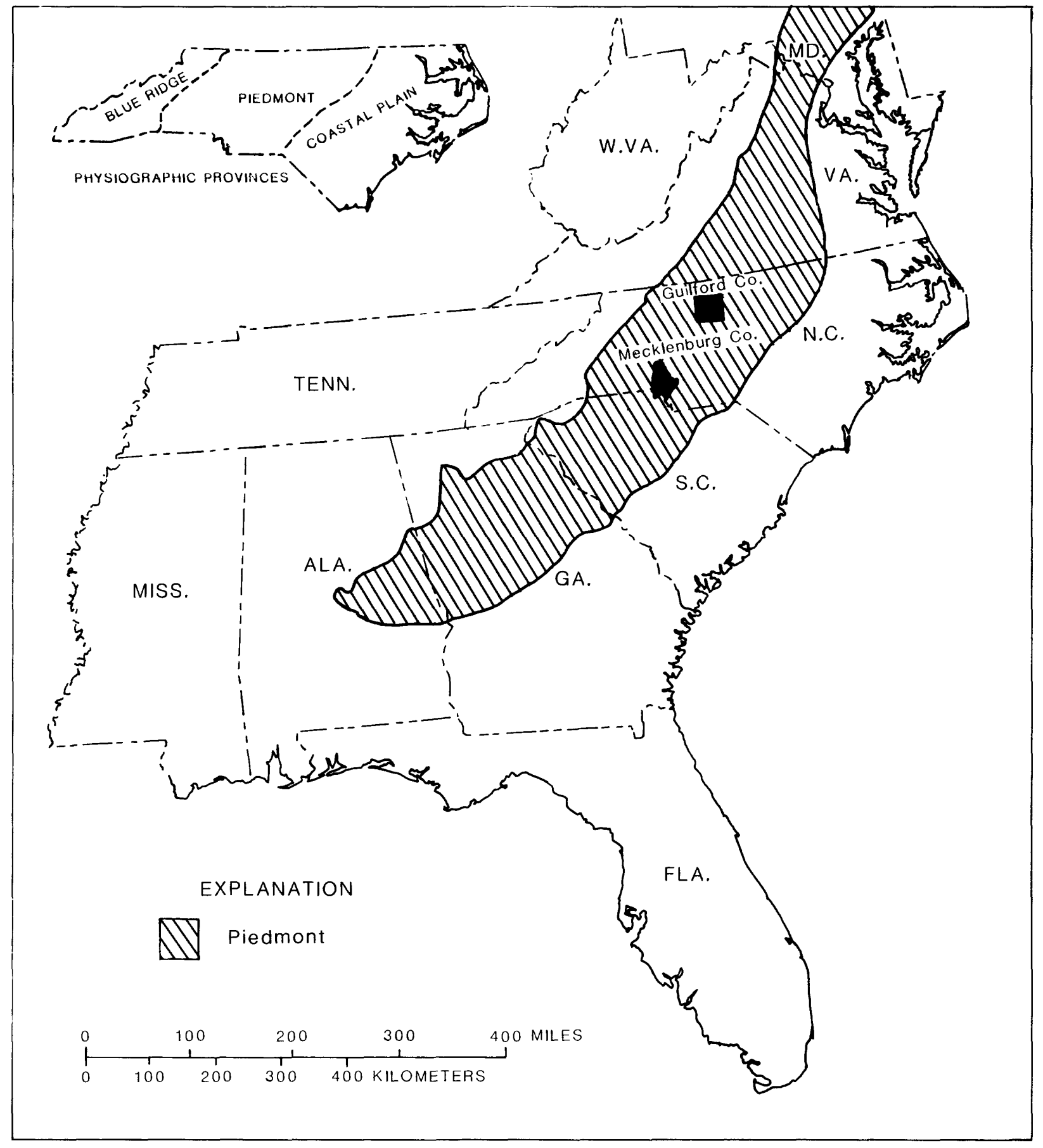

Figure 1.--The Piedmont province of the eastern United States and the physiographic provinces of North Carolina. 
The Piedmont consists of low, rounded hills and long, rolling northeast-trending ridges with up to a few hundred feet of local relief. Land elevation gradually rises from about 150 feet above sea level along the Piedmont's eastern boundary to 1,900 feet along the western boundary at the foot of the Blue Ridge front.

The rolling topography is the result of streams acting on rocks of unequal resistance. Isolated hills with summit heights standing above the upland surface are remnants of extremely erosion-resistant rock. In contrast to the topography of the crystalline-rock terrane of most of the Piedmont, erosion has produced low lands in the soft sedimentary rocks of the Triassic basins.

The typical Piedmont topographic surface described by Fenneman (1938) is practically all hillside or valley side. The region has a well integrated drainage system and, in nearly all aspects, qualifies as having reached topographic maturity as defined by Thornbury (1954). LeGrand (1958 and 1984) notes that in the network of closely spaced perennial streams the upland divide is everywhere less than a mile and commonly less than half a mile from a valley.

\section{Geology}

The geology of the North Carolina Piedmont province is very complex; the bedrock consists of folded and fractured metamorphosed sedimentary and igneous basement rocks. Intruded into these metamorphic rocks are lesser bodies of unmetamorphosed igneous rocks. Typical bedrock lithologies include granite, gneiss, schist, quartzite, slate, and phyllite.

Downfaulted into the basement complex are several basins (Triassic basins), which are grabens where sedimentary rock occurs.

The regional geology of the Piedmont basement is only generally understood. The crystalline igneous and metamorphic sequences may have undergone two or three regional metamorphic events and as many as four major deformation events from the Precambrian through the Paleozoic. The complex nature and variable degrees of metamorphism found in the Piedmont make precise dating of these events impossible at present. More detailed discussions of recent hypotheses for these events can be found elsewhere 
(Ragland and others, 1983; Farrar, 1985; Russell and others, 1985; Wehr and Grover, 1985). Various periods of plate tectonic activity, along with the associated formation of rift margins, are believed to be responsible for these events. The Piedmont can be divided into northeast trending paralle1 geologic belts. Traversing from the southeast, the major geologic belts are the Carolina slate belt, the Raleigh belt, the Charlotte belt, the Kings Mountain belt, and the Inner Piedmont belt (Danie1, 1987).

The rock-type classification scheme based on lithologic and geohydrologic properties developed by Daniel (1987) for the Piedmont and Blue Ridge provinces of North Carolina has been used in this study. The near-surface earth materials of the Piedmont consist of a three-stage system which, from top to bottom, contains (1) a regolith zone, (2) a transition zone, and (3) underlying fractured crystalline bedrock (fig. 2).

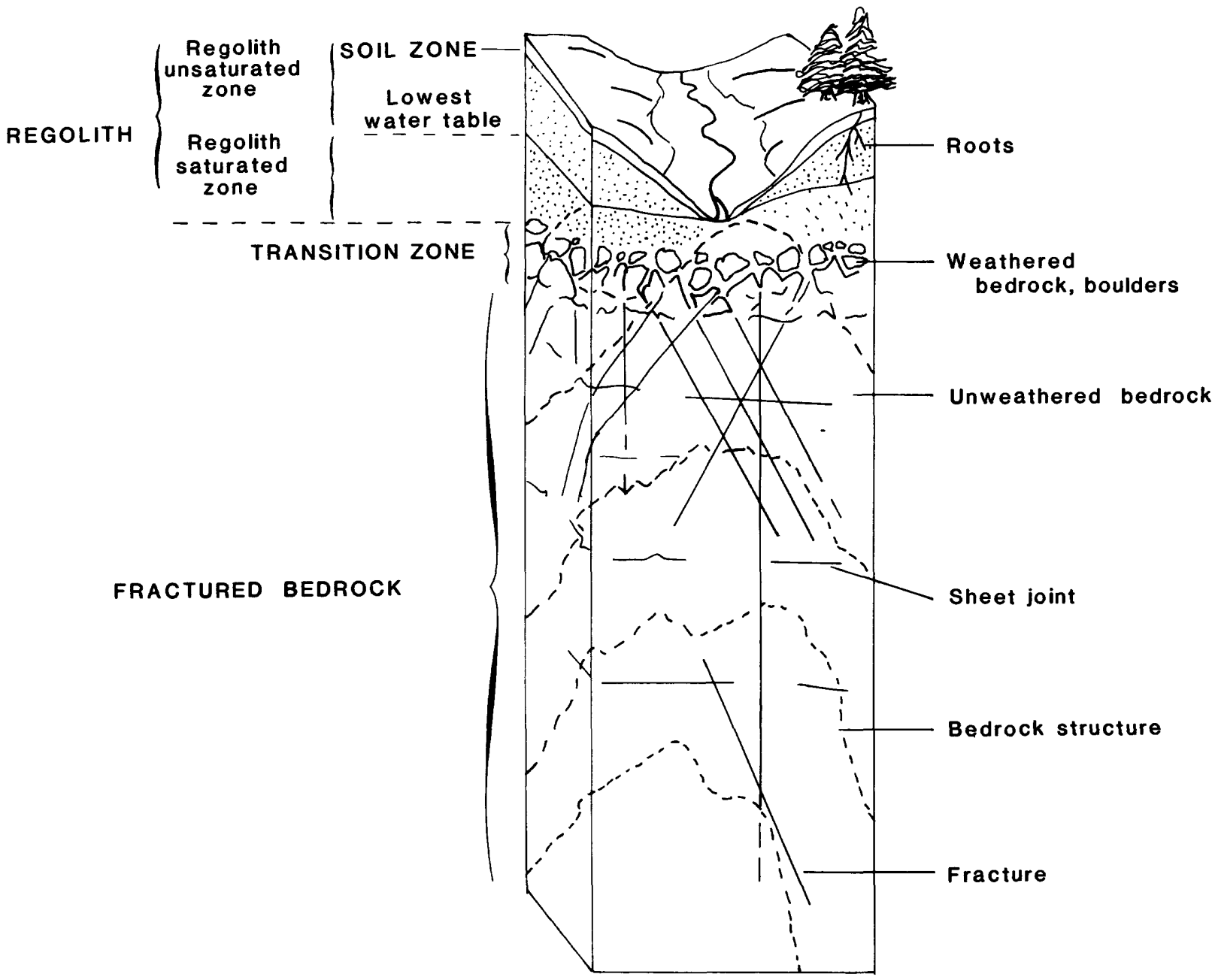

Figure 2.--Conceptual structure of the Piedmont ground-water system (modified from Heath, 1984). 
Collectively, the uppermost layer is the regolith, which is composed of saprolite, alluvium, and soil (Daniel and Sharpless, 1983). The regolith zone consists of an unconsolidated or semiconsolidated mixture of clay and fragmental material ranging in grain size from silt to boulders.

Saprolite is the clay-rich, residual material derived from in-place weathering of bedrock. Saprolite deposits represent leached deposits and, being granular material with principal openings between grabens, differ significantly in texture and chemical composition from the parent rock which is unweathered, crystalline rock having principal openings along fractures. Since saprolite is the product of in-place weathering of the parent bedrock, some of the textural features of that bedrock are retained within the saprolite. Evidence of relic quartz veins, dikes, and shear zones are commonly seen in outcrops. Alluvial deposits are unconsolidated sediments deposited by streams and rivers. Soil is referred to as the natural medium for the growth of plants. Saprolite is the dominant deposit in this unconsolidated zone, with soil deposits generally restricted to the uppermost layer, and alluvium deposits restricted to locations of current and former stream channels and river beds.

The transition zone is where unconsolidated material grades into bedrock and consists of saprolite and partially weathered bedrock. Here, particle size ranges from silts and clays to large boulders of unweathered bedrock. The thickness of this zone depends a great deal on the texture and composition of the parent rock. The best defined transitional zones are usually associated with highly foliated metamorphic parent rock, while those of massive igneous rocks are often poorly defined or nonexistent (C.C. Daniel, III, U.S. Geological Survey, oral commun., 1985). In the Piedmont, 90 percent of the records for cased bedrock wells show combined thicknesses of 97 feet or less for the regolith and transition zones (Danie1, 1987).

The uppermost part of the Piedmont crystalline bedrock contains numerous closely spaced fractures which can be related to the local and regional tectonic history of the area. As a general rule, very few fractures occur in the Piedmont bedrock at depths greater than 400 feet (LeGrand, 1967). 


\section{$\underline{\text { Soi1s }}$}

Most Piedmont soils have formed largely from saprolite derived from the underlying parent rocks. Some soils have developed on stream-valley alluvium. Soils are a product of their local and regional environment. Geology, geomorphology, and climate, in addition to topography, moisture, and vegetation, influence the characteristics of soil cover. Combinations of factors give rise to a number of diverse soils that fit into locally and regionally recurring patterns.

Daniels and others (1984) classified four major soil systems within the Piedmont based on the major kinds of bedrock:

1. The felsic crystalline terrains composed largely of granite, gneiss, mica gneiss, and schist;

2. The Carolina slate belt of bedded argillites, felsic volcanics, and mafic volcanics;

3. The Triassic basins with mudstones, sandstones, shales, and conglomerates; and

4. The mixed mafic and felsic rocks; a complex area of granites, diorites, gabbros, and other rocks.

In the felsic crystalline area, most deeper soil horizons are clayey, but some soils originating from the coarser grained rocks, such as granite, have clay-loam or loamy-sand deeper horizons. Soils derived from Carolina slates have high silt contents, overlie relatively thin saprolite layers in comparison with the felsic crystalline area, and have low permeability in the deeper horizons. Triassic basin soils have more swelling clays in their deeper horizons than other soils. The mafic soils (from mafic dikes) are plastic and usually a reddish color.

In this study, physical parameters of soils, including permeability and available water capacity provided by the U.S. Soil Conservation Service (1978), were used to construct the detailed data base necessary to compare ground-water quality characteristics with soil type. These parameters have been included in the data set but were not used in the data analysis. 


\section{Land Use}

Land Use Data Analysis maps (LUDA maps; Anderson and others, 1976) provide data on a regional scale for land use in the Piedmont. These maps were generated in the early 1970's using remote-sensing satellite data.

Estimates of the relative amount of area covered by the different landuse types were determined from LUDA maps. Land-use types lying along the 78-, 80-, and 82-degree meridians, and along the 35- and 36-degree parallels were determined from the North Carolina LUDA maps. First, the distances along each latitude or longitude line for each land-use type were measured and totaled. Then, the total for each land use was divided by the total for all the lines sampled to give a percent of the total area covered by each land use. The result of these calculations are shown in table 1 . This analysis indicates that about 65 percent of the North Carolina Piedmont land area is forest, about 25 percent is crop land, and about 6 percent is urban and residential.

Table 1.--Approximate percentages of major land uses of the Piedmont of North Carolina

[LUDA, Land Use Data Analysis]

\begin{tabular}{|c|c|}
\hline $\begin{array}{c}\text { LUDA } \\
\text { land use }\end{array}$ & $\begin{array}{l}\text { Piedmont } \\
\text { percent }\end{array}$ \\
\hline Residential and farm buildings & 4.2 \\
\hline Commercial and services & .67 \\
\hline Industrial & .23 \\
\hline Transportation, communications, and utilities & .34 \\
\hline Mixed urban & .32 \\
\hline Other urban or built-up land & .59 \\
\hline Cropland and pastures & 25 \\
\hline Deciduous forest & 24 \\
\hline Evergreen forest & 10 \\
\hline Mixed forest & 32 \\
\hline Reservoirs & 1.2 \\
\hline Forested wetland & .85 \\
\hline Transitional areas & .36 \\
\hline Other & .24 \\
\hline
\end{tabular}

Land-use data from Anderson and others, 1976. 


\section{HYDROGEOLOGIC FRAMEWORK AND CONCEPTUAL MODEL OF THE FLOW SYSTEM}

Heath's (1984) concept of the ground-water system for the Piedmont and Blue Ridge provinces has been adopted as the conceptual model for this study with slight modifications to emphasize the transition zone between the regolith zone and the bedrock.

The fundamental structure of the ground-water system is shown in figure 2. The components of the system are:

1. The unsaturated zone in the regolith, which generally contains the organic layers of the surface soil;

2. The saturated zone in the regolith;

3. The transition zone between the regolith and bedrock; and

4. The fractured crystalline bedrock system.

\section{Regolith Unsaturated Zone}

The unsaturated zone extends from the land surface down to the water table, which is the top of the saturated zone. The pore spaces of the regolith in the unsaturated zone contain both air and water. The unsaturated zone usually ranges from 5 to 50 feet in thickness. Daniel (1987) found a mean depth to the water table of 31.3 feet in an examination of 2,326 Piedmont wells. Water moves down from the land surface through the soil zone by intergranular flow through the larger pore spaces and passages left by burrows or decayed roots. Roots from surface vegetation can grow to 30 feet below land surface but more commonly spread laterally near the surface. At the base of the soil zone, which is generally 3 to 8 feet thick, the average grain size abruptly decreases with a corresponding decrease in pore size as the water enters the saprolite (C.C. Daniel, III, U.S. Geological Survey, written commun., 1985). At this point water movement may also be diverted somewhat by relic structures of foliation or folds in the saprolite, which are remnants from the parent rock.

The total porosity of soil is commonly around 55 percent, and its specific yield is about 40 percent (Heath, 1983). Saprolite has a total porosity of 35 to 50 percent near land surface (fig. 3), which decreases at depth, and a specific yield of 20 percent (Daniel and Sharpless, 1983). 


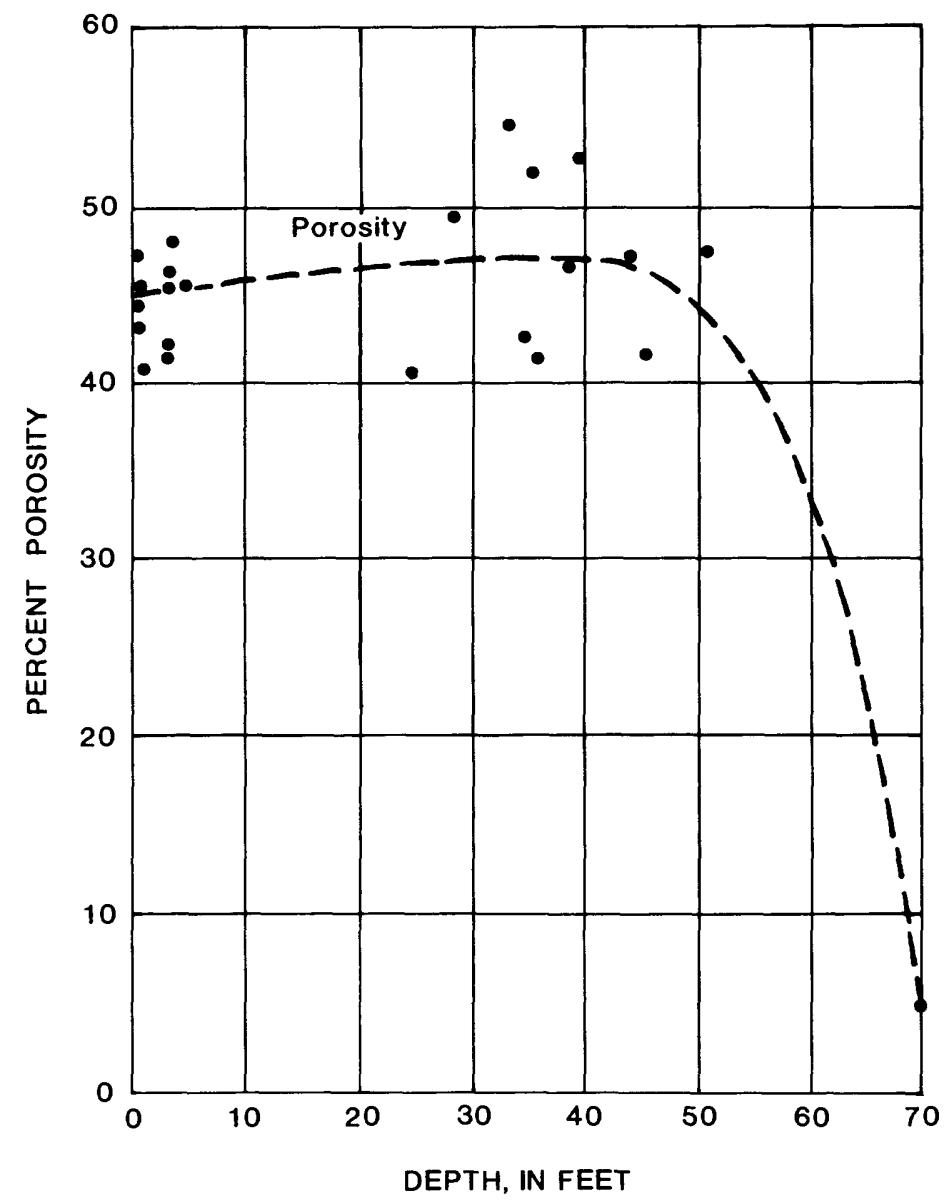

Figure 3.--Relation of porosity of saprolite with depth (after Stewart, 1962).

Topsoil in Piedmont soils to a depth of 7 to 10 inches was reported to have a mean hydraulic conductivity of 5.7 inches per hour (11.4 feet per day), and the subsoil, 7 to 20 inches below land surface, has a mean hydraulic conductivity 1.8 inches per hour (3.6 feet per day) (Lutz, 1969). These values are in line with the hydraulic conductivity values for saprolite reported by Heath (1980) that range from 0.5 to 10 inches per hour ( 1 to 20 feet per day). However, the hydraulic conductivity of saprolite is not the same in all directions. This anistropy may take the form of preferential permeability along the direction of relic structures within the saprolite.

\section{Regolith Saturated Zone}

The regolith saturated zone is that interval below the water table and above the transition zone. Daniel has calculated the median saturated 
thickness of the regolith and transition zone from records of 1,749 watersupply wells in the Piedmont of North Carolina to be 13 feet (Danie1, 1987). The median saturated thickness was shown to be a function of topography: beneath draws and valleys, it was 28 feet thick; below slopes and flats, it was 15 feet; and beneath hills and ridges, it was 9 feet.

The saturated regolith provides the bulk of the water storage within the Piedmont ground-water system (Heath, 1980). This concept is illustrated in figure 4. In the Piedmont ground-water system, the regolith has a specific yield of around 20 percent (Daniel and Sharpless, 1983), whereas the porosity of the bedrock ranges from 0.01 to 2 percent (Heath, 1984). The depth-porosity relation described by stewart (1962) is shown in figure 3. The amount of ground water in storage as a function of the saturated thickness of the regolith has been calculated by Danie1 (C.C. Danie1, III, U.S. Geological Survey, written commun., 1985) and is presented as figure 5.

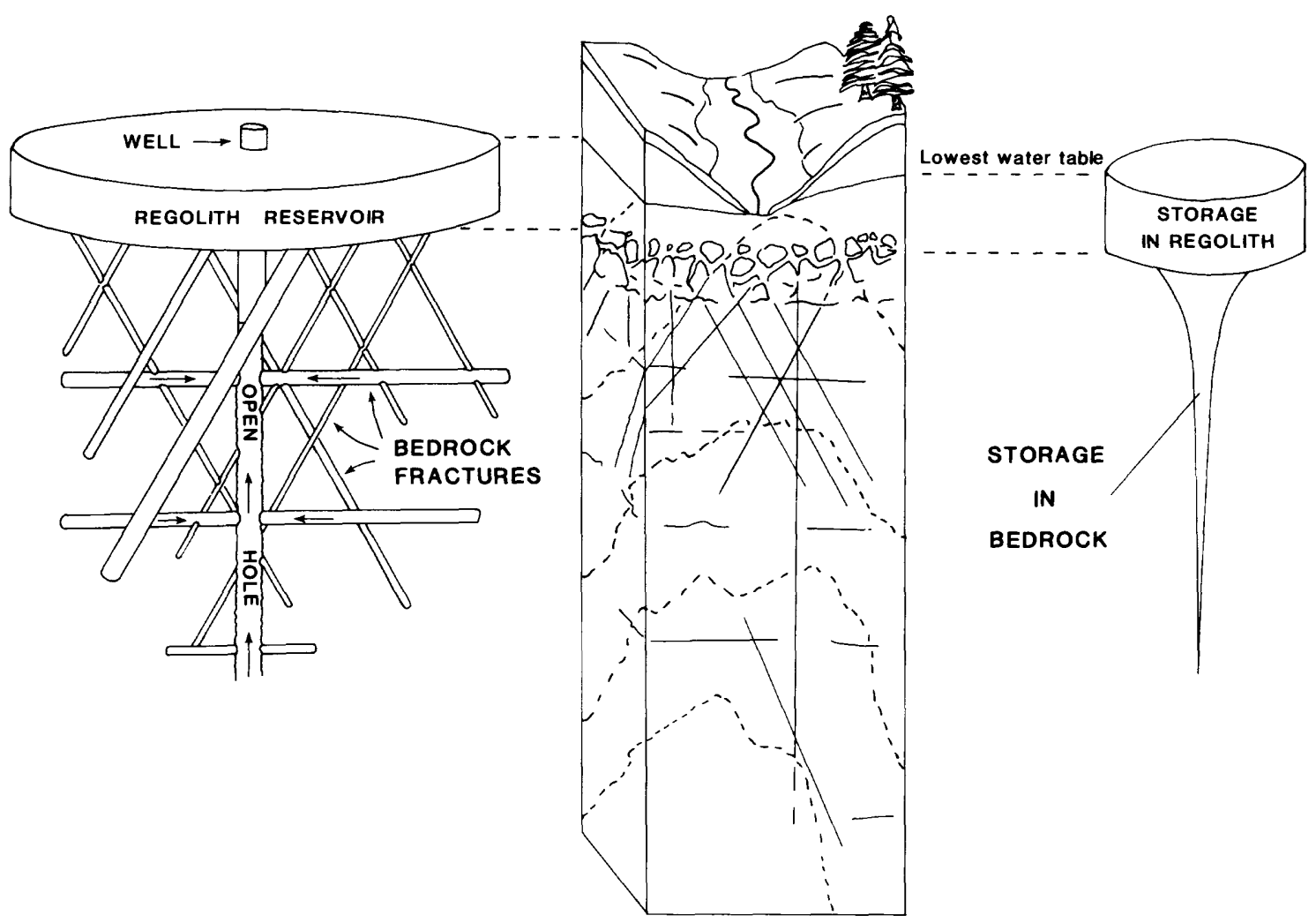

Figure 4.--Water storage within, and the reservoir-pipeline conceptual model of the Piedmont ground-water system (modified from Heath, 1984). 


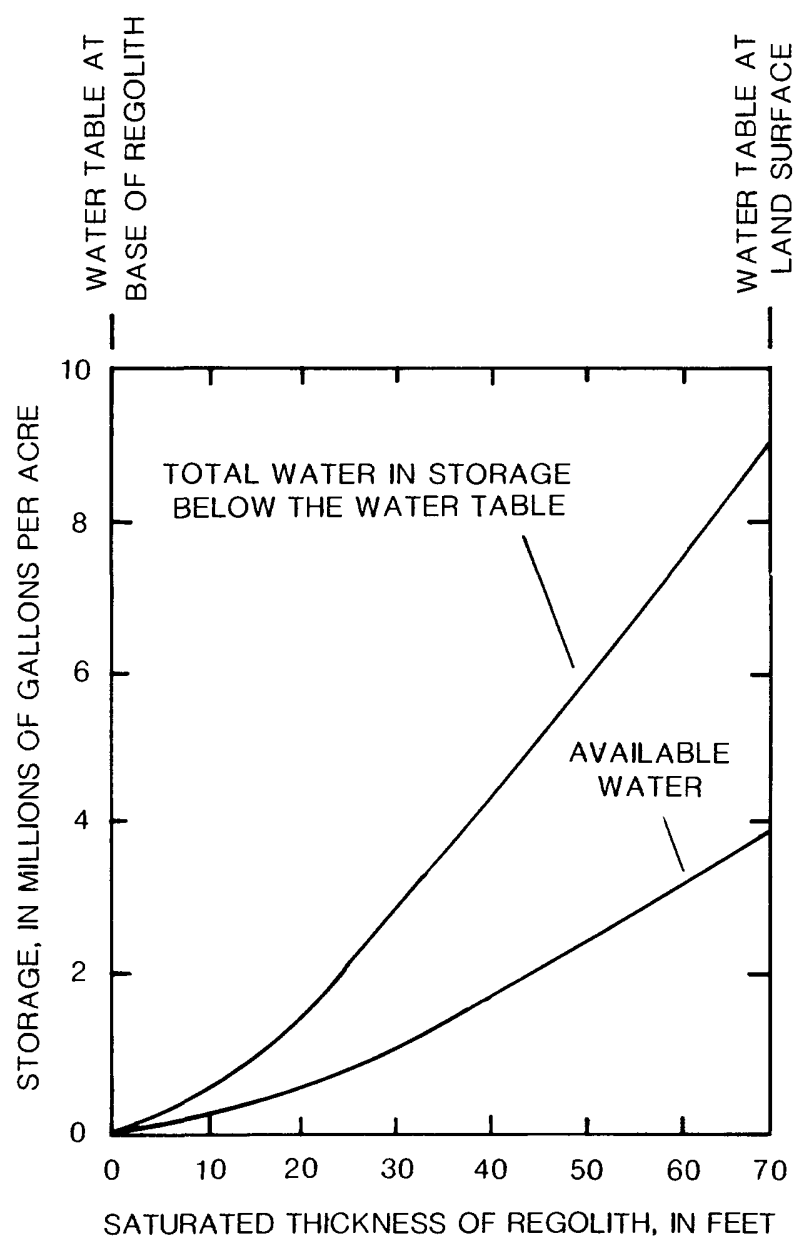

Figure 5.--Relation of ground-water storage and saturated thickness (after C.C. Danie1, III, U.S. Geological Survey, written commun., 1986).

As illustrated in figure 4, the regolith serves as a reservoir supplying water to interconnected fractures within the bedrock. In general, wells in the Piedmont are cased through the regolith, with open hole through enough of the bedrock to intercept enough fractures to furnish acceptable yields. The bedrock fractures serve as pipelines between the well and the regolith reservoir.

The depth to water table is largely a function of topography. Based on data from 2,326 water-supply wells, the median water level in wells located in draws and valleys is 20 feet, in slopes and flats 25 feet, and in hills and ridges 32 feet (Daniel, 1987). Depth to water table at any one place varies with ground-water recharge and continual discharge. An example of 
the response of water level due to variation in rainfall is shown in figure 6. In this example, ground-water recharge (in excess of discharge) resulting from heavy rains in late winter, when evapotranspiration is low, is reflected by a peak in the water-table hydrograph appearing a few days after heavy rainfall in late March. The time after a storm that the peak appears in the water level is directly related to the vertical hydraulic conductivity of the material in the unsaturated zone and the depth to water table. The hydrograph also shows that little recharge took place during the growing season (April through September) even though the area received significant rainfall during these months. The declining water level indicates continuing ground-water discharge that is not equaled or exceeded by recharge until fall, when evapotranspiration is low. Similar seasonal
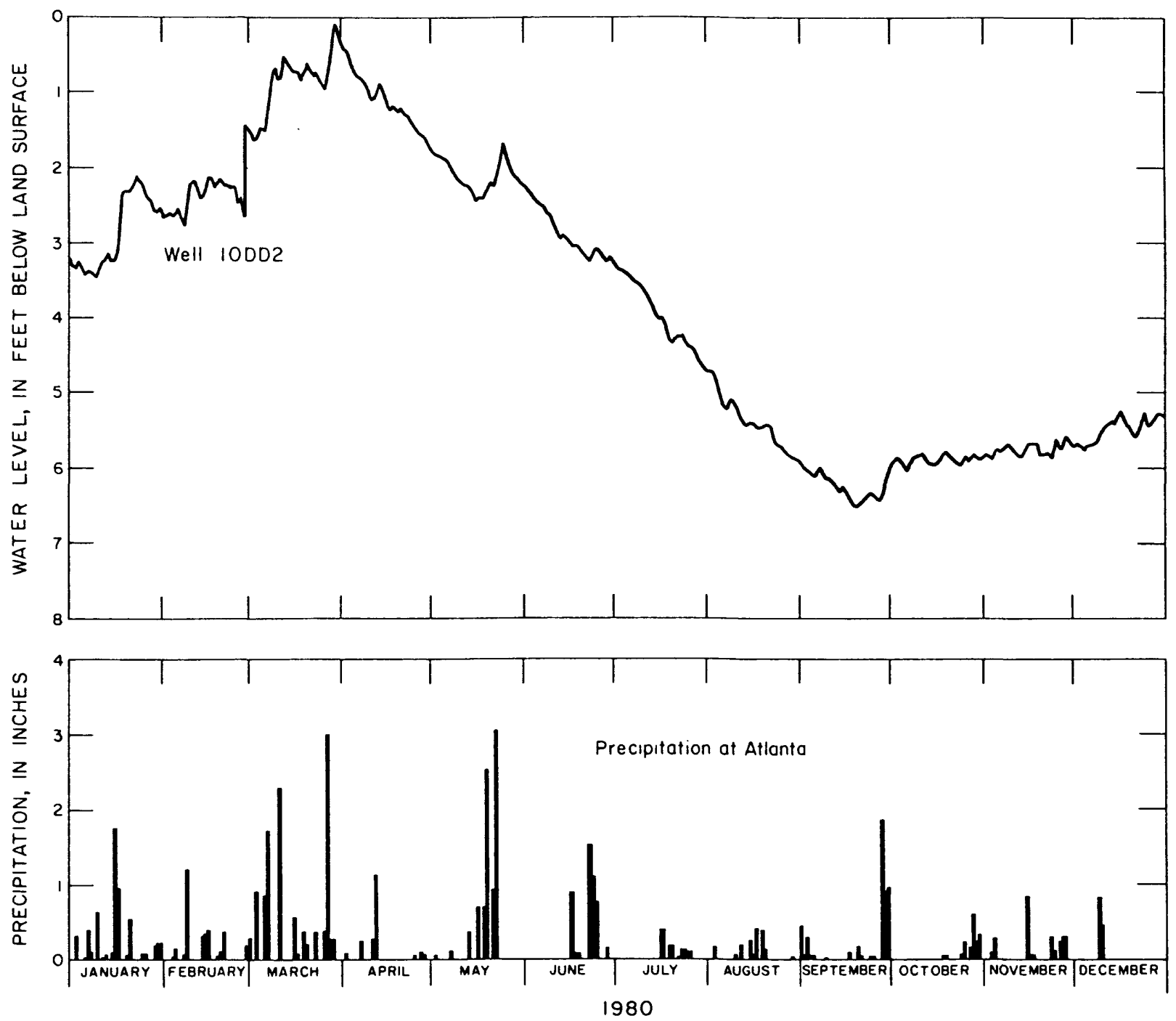

Figure 6.--Response of water-level change to rainfall (from Cressler and others, 1983). 
fluctuations of the water table are also shown in the hydrograph for a well located in Iredell County, North Carolina (fig. 7).

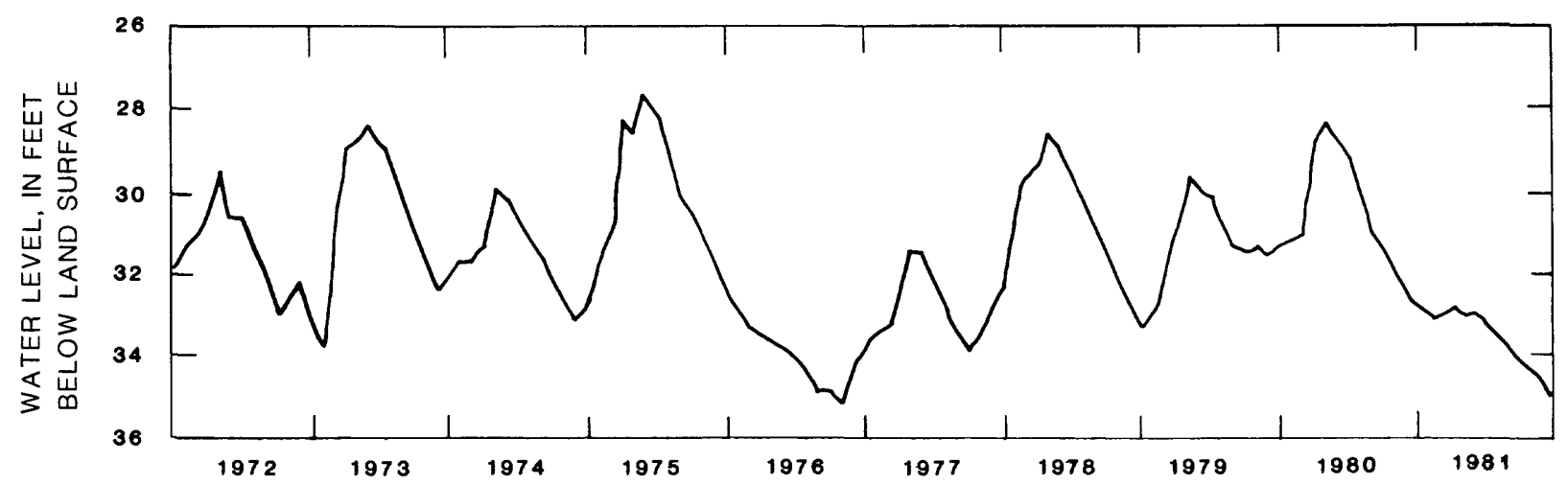

Figure 7.--Seasonal fluctuations in water-table depth in a well in Iredell County, North Carolina

(from LeGrand, 1984).

\section{Transition Zone}

At the base of the regolith there is generally a transition zone of weathered rock, boulders, and saprolite. Careful augering of three wells showed this transition zone to be approximately 15 feet thick at the Guilford County, North Carolina, test site shown in figure 8 (C.C. Daniel, III, U.S. Geological Survey, written commun., 1985). This zone has been found in Georgia, Maryland, and North Carolina and reported by Stewart (1962), Nutter and Otton (1969), and Daniel (C.C. Daniel, III, U.S.

Geological Survey, written commun., 1985), respectively. They describe this zone as being more permeable than the upper regolith and slightly more permeable than the soil zone. This observation is substantiated by reports from well drillers of so-called "first water" (C.C. Danie1, III, U.S. Geological Survey, written commun., 1985) in drillers' logs (Nutter and Otton, 1969).

The high permeability of the transition zone is probably due to incomplete weathering in the upper regolith. Chemical alteration of the bedrock has progressed to a stage of minute fracturing of the crystalline rock, yet it has not progressed so far that the rock minerals have been altered to clays, which would clog the tiny fractures (C.C. Daniel, III, 


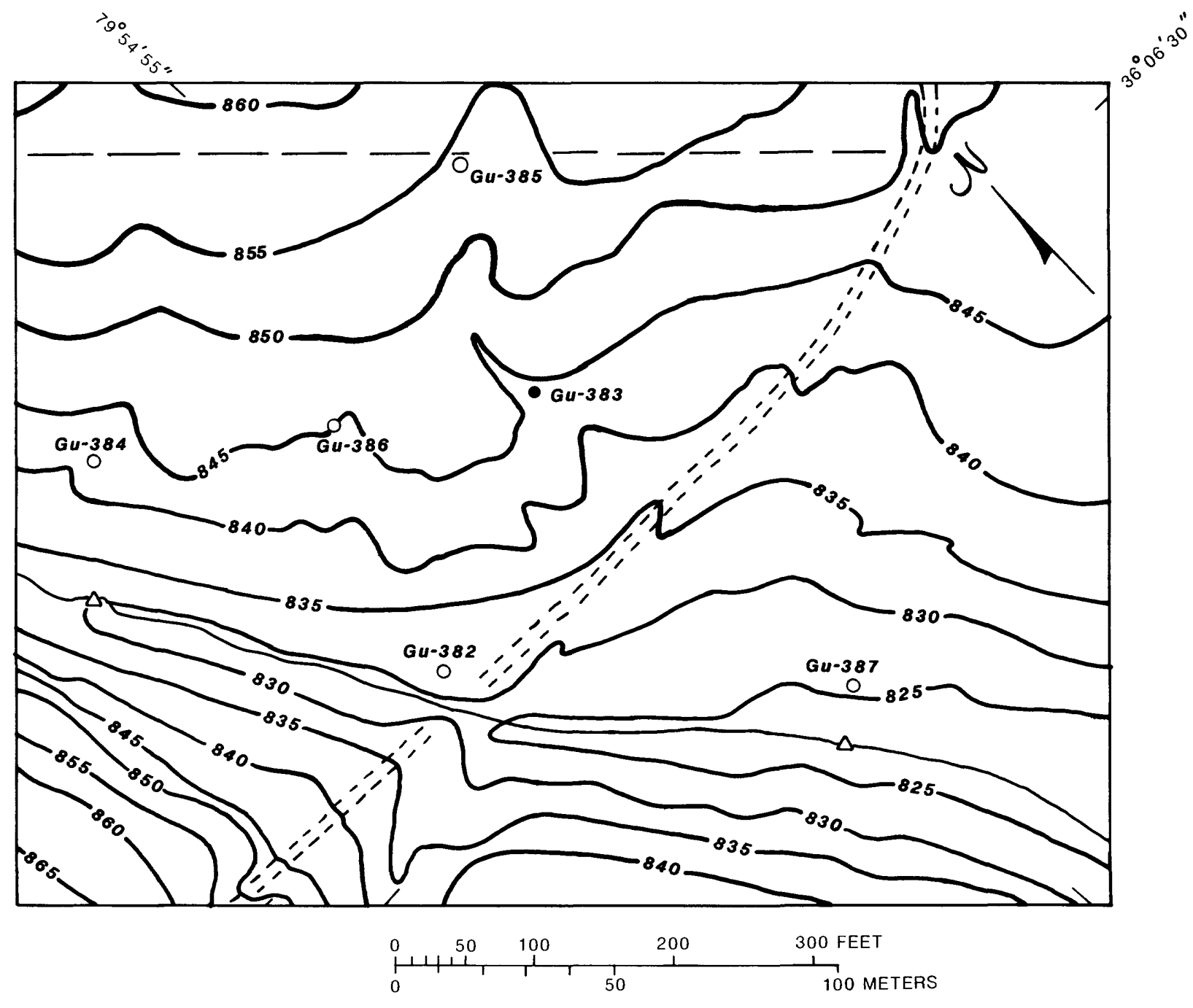

EXPLANATION

$-830-$ ALTITUDE CONTOUR-- Shows land surface altitude. Contour interval 5 feet. Datum is sea level

$\triangle \quad$ Streamflow station (nonrecording)

$0^{\mathbf{G u - 3 8 6}}$ Observation well and number (bedrock)

Gu-383 Production well

- Fence

二ニニ二ニ Road

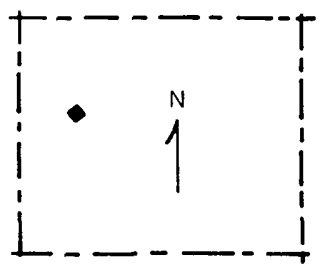

Site location in Guilford Co.

Figure 8.--Locations of data-collection sites and topography at the Greensboro-High Point Regional Airport test site (from Daniel and Sharpless, 1983).

U.S. Geological Survey, written commun., 1985). An idealized weathering profile by Nutter and Otton shown in figure 9 illustrates the effect of degree of weathering on permeability. 


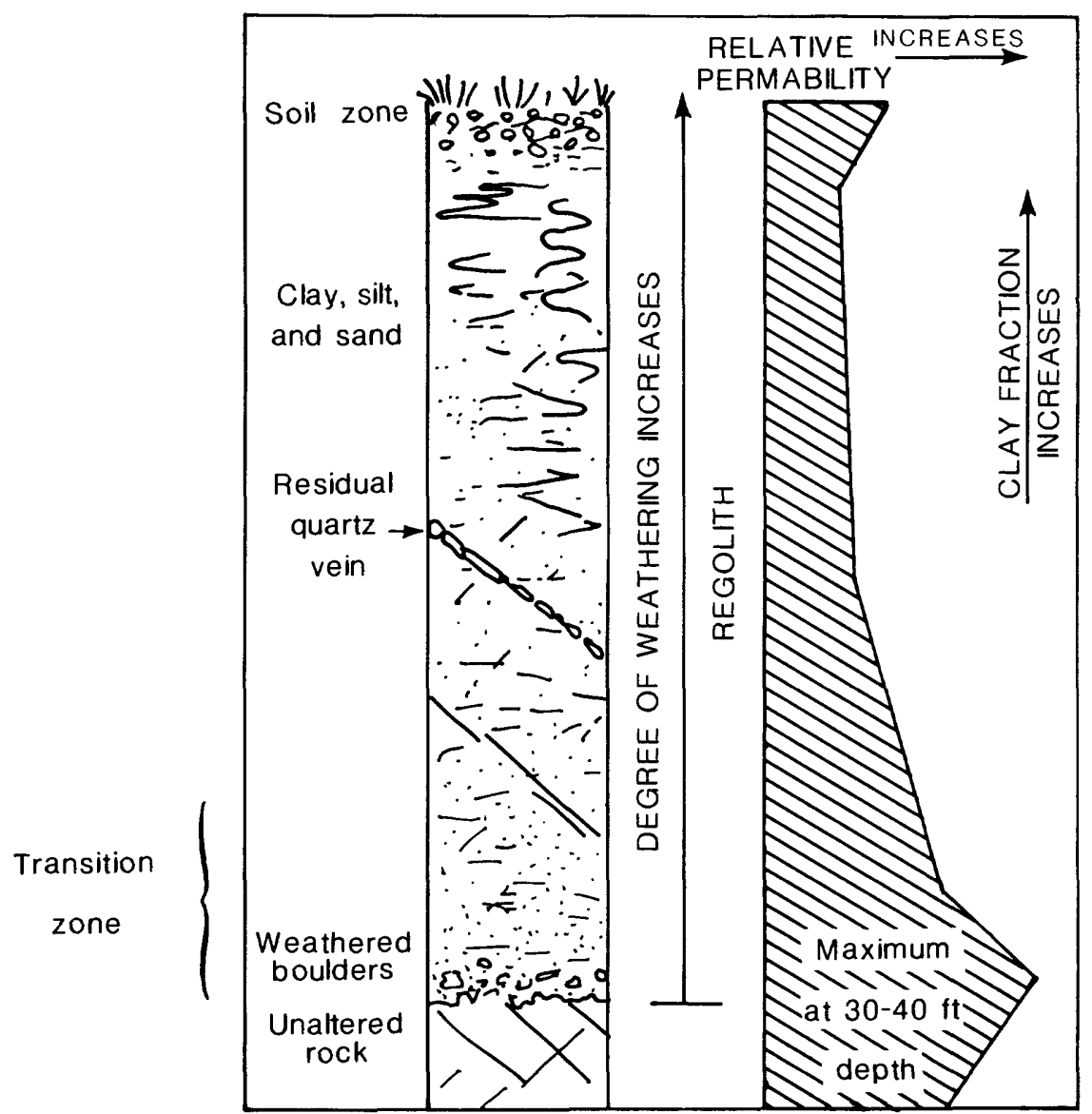

Figure 9.--An idealized weathering profile through the regolith showing relative permeability

(after Nutter and Otton, 1969).

The presence of a high-permeability zone on top of the bedrock may create a zone of concentrated flow within the ground-water system. Daniel (C.C. Danie1, III, U.S. Geological Survey, written commun., 1985) cites the case where well drillers find water in the transition zone, yet end up with a dry hole after setting casing through the regolith and transition zone into the unweathered bedrock. In this case, the ground water occurs primarily in the transition zone, where there is poor connection between the regolith reservoir, the bedrock fracture pipeline system, and the well. Daniel comments that the transition zone may serve as an interval where relatively rapid movement of contaminated ground water can take place. 


\section{Fractured Bedrock}

Ground-water flow within the crystalline bedrock occurs within fracture systems. LeGrand (1967) discussed what he considered to be the six common types of fracture patterns (fig. 10) that influence yields to wells. These fractures are reported to be more common near the surface and beneath valleys, draws, and surface depressions (Heath, 1980), and are considered to be zones of weakness that allowed the initial development of valleys and draws at these locations. Fracture openings are wider near the bedrock surface and decrease in size and number with depth due to increasing lithostatic pressure.

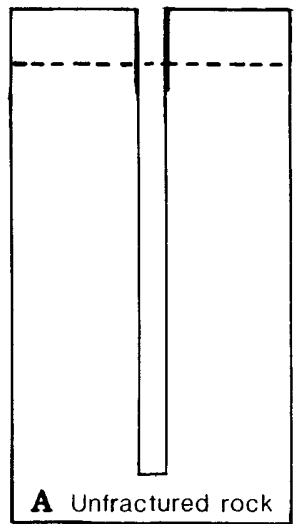

3 percent

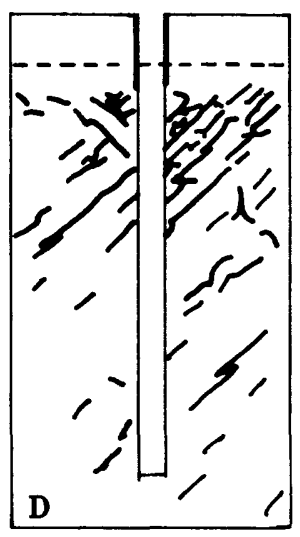

32 percent

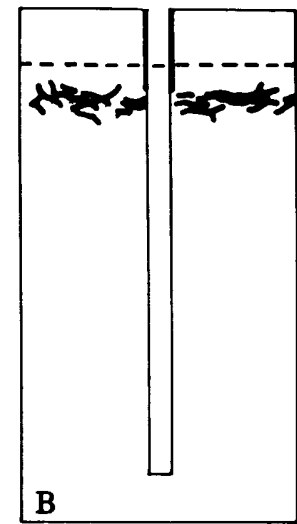

20 percent

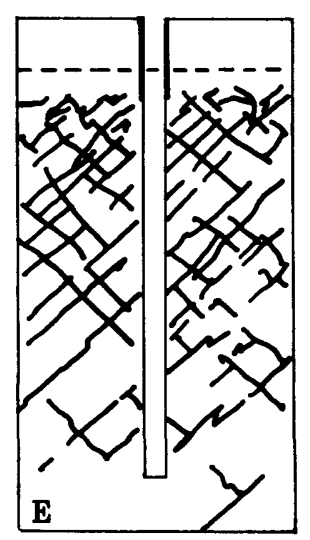

25 percent

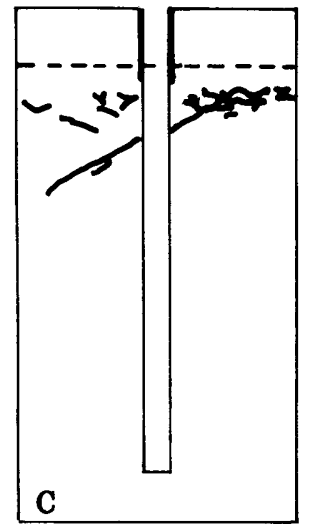

15 percent

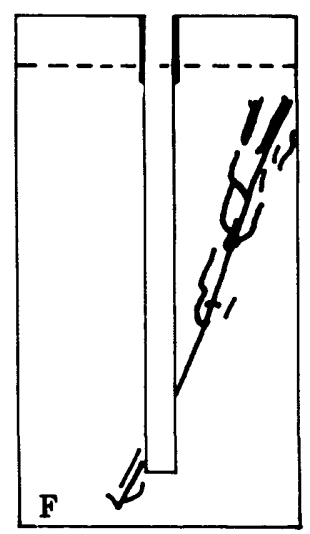

5 percent

EXPLANATION

-.- Water table

Rock fracture

5 percent - Frequency of occurance for each fracture system

Figure 10.--Six common types of fracture systems in the Piedmont (from LeGrand, 1967). 
Heath indicates that few fractures below 300 to 400 feet from land surface contain substantial amounts of water, and that those which do bear water at depth are probably associated with faults. However, Cressler and others (1983) found that for the Atlanta, Georgia, area, nearly horizontal stress-relief fractures at depths of 400 feet or more were often associated with high-yielding wells. When surface material is removed by erosion, nearly horizontal stress-relief fractures develop and widen in response to the reduction in compressional stress. Daniel also reports high-yielding we11s at depths over 500 feet in the North Carolina Piedmont (Danie1, 1987). Fractures are planar features oriented along zones of lithologic and structural weakness. Water can move along the fractures with relative ease to discharge points such as wells or to natural discharge areas in stream valleys. Non-horizontal fractures may account for dramatically asymmetrical patterns of water-level decline that may be seen around a pumped well or the more rapid movement of water and contaminants in one direction than in another, creating aniostrophy in the bedrock aquifer. The hydrologic conductivity of the fractured bedrock is generally 0.001 to 3 feet per day (Heath, 1984). The primary porosity of the bedrock ranges from about 0.01 to 2 percent (Heath, 1984).

In general, the mineral assemblages determine the degree to which water will dissolve aquifer material. For example, quartz is resistant to chemical weathering and will dissolve much more slowly than less resistant ferromagnesium minerals such as biotite and hornblende and numerous iron minerals such as pyrite and magnetite. Generally, the mafic igneous rocks such as diorite-gabbro contain more ferromagnesium minerals and are more susceptible to chemical solution than the minerals of felsic rocks such as granite. Weathering of the ferromagnesium minerals produce solution openings and channels in the mafic rock units.

Ground water from a typical granite, composed largely of sodium and potassium feldspars, should have relatively high concentrations of sodium bicarbonate. Calcium and magnesium bicarbonate concentrations can be high in ground water moving through mafic rocks, such as gabbro, which is composed largely of calcium feldspars and ferromagnesium minerals. Ground water from certain metavolcanic and mica-schist units contain high concentrations of iron (Hem, 1970). However, these simple relationships are complicated if there is mixing of waters from adjacent rock types of different compositions or if the host rock is intermediate in composition. 
Because the natural chemical quality of ground water is affected by the minerals in the regolith and bedrock, which form the hydrogeologic framework for the Piedmont ground-water system, the natural water quality should be considered when attempting to determine water-quality differences resulting from different land uses. The significance of the effects of geology and soils on the ground-water quality are described in the data-analysis section of the report.

\section{Flow Hypotheses}

Several aspects of the ground-water flow system in the Piedmont are particularly significant geochemically. In describing ground-water recharge and discharge and the functions of a ground-water system, Heath (1983, p. 14) states:

Hydraulically, this system serves two functions: it stores water to the extent of its porosity, and it transmits water from recharge areas to discharge areas. Thus, a ground-water system serves as both a reservoir and a conduit.

Water enters ground-water systems in recharge areas

and moves through them, as dictated by hydraulic gradients and hydraulic conductivities, to discharge areas.

In the humid part of the country, recharge occurs in all interstream areas--that is, in all areas except along streams and their adjoining flood plains. The streams and flood plains are, under most conditions, discharge areas.

These general conditions are assumed to apply in the Piedmont of North Carolina.

The generalized flow system in the Piedmont as represented in figure 11 occurs within a closely-spaced network of streams typical of the mature topography of the Piedmont. Ground-water flow is toward these streams, and the shape of the water table mimics the topography of the land surface, 


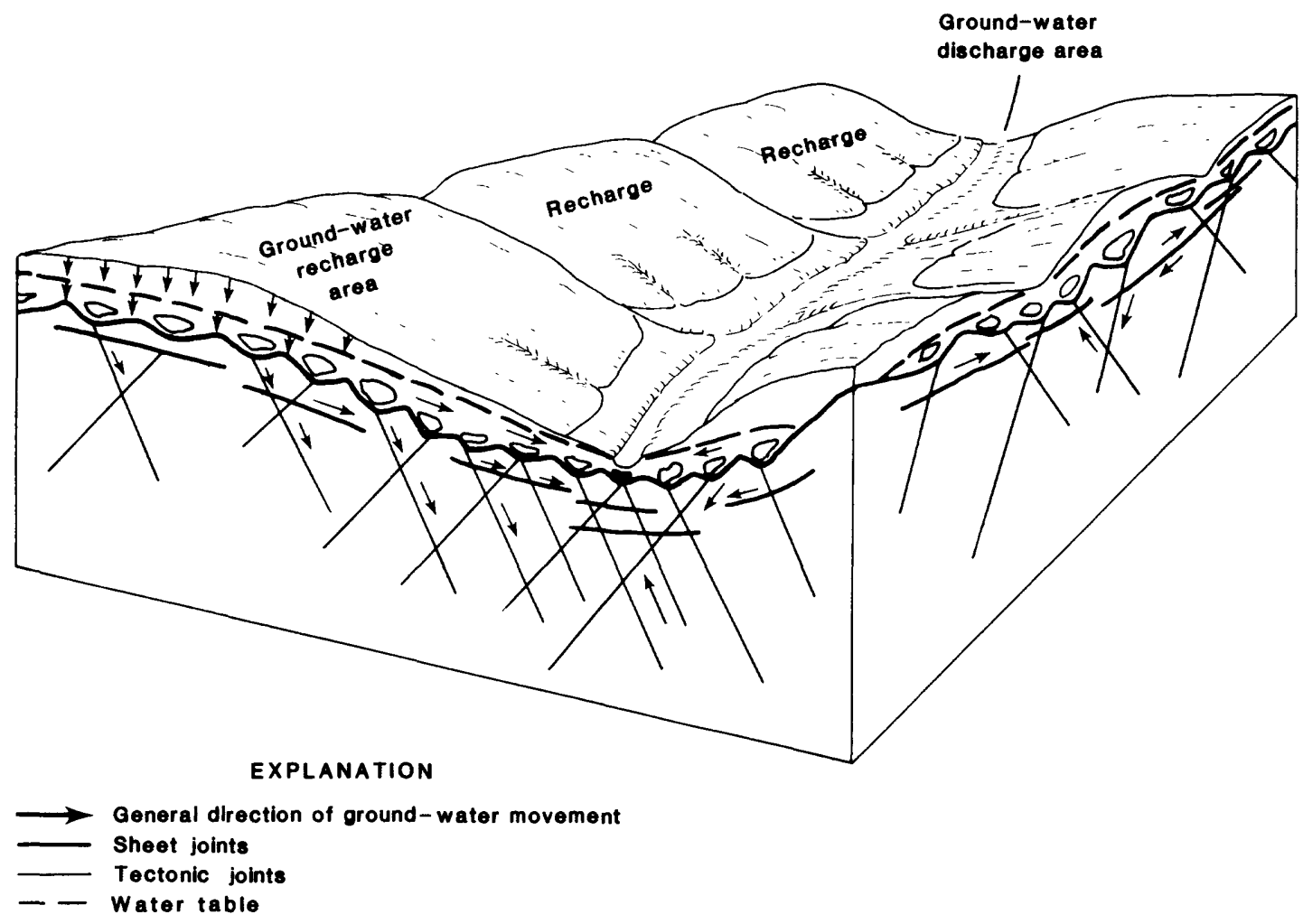

Figure 11.--Generalized ground-water flow system in the Piedmont (from Heath, 1980).

although with subdued relief. Thus, surface topography can be used to predict the natural direction of ground-water flow. The distance between the point where a drop of water or waste enters the system and the point where it discharges into the stream down slope is commonly less than a half mile (LeGrand, 1958). Most of the natural flow in the system is probably confined to the upper 30 feet of bedrock, where fractures are concentrated, and the overlying transition zone, which apparently has the highest hydraulic conductivity of any part of the hydrogeologic system (C.C. Daniel, III, U.S. Geological Survey, written commun., 1985). However, flow probably also occurs in the deeper fractured system in a manner harder to predict by local surface topography. In the deeper system, regional topography or structural features may result in flow over long distances and long groundwater residence times in the fractured rock.

The ground-water flow system in the Piedmont is directly connected to the surface-water system. The annual contribution of ground water to total streamflow for 11 streams flowing through the Piedmont is estimated to average 44 percent (Harned and Daniel, 1987). Consequently, it is a concern that ground-water contamination will eventually discharge to streams that are water-supply sources. 
Because of the interconnection of the ground- and surface-water systems in the Piedmont, a drainage basin large enough to contain a perennial stream can serve as a basic unit for the description of ground-water quality (LeGrand, 1984). Each drainage basin is a flow-system cell similar to, and yet separate from, surrounding basins. Although not all of the ground-water flow for a particular area is confined within a single drainage basin, it should be possible to generalize, with a reasonable degree of confidence, about ground-water quality of larger regions from data collected in small drainage basins. This is a basic assumption used in this study.

Hypotheses about the Piedmont ground-water flow system relevant to this and future studies of the system include:

1. The transition zone between bedrock and regolith serves as a primary transmitter of contaminated ground water. The regolith serves as the principal reservoir of ground-water contamination.

2. Attenuation of ground-water contamination in the regolith is related to the degree of weathering and composition of regolith material and the hydraulic conductivity, gradient, and porosity of the material.

3. The velocity of contaminant movement can be highest within the fractured bedrock system, particularly under stressed conditions.

4. The deeper zones in basement rock generally contain the best quality water in the system due to contaminant attenuation in the regolith.

5. Geomorphological analysis can be used to identify fracture zones that help predict general subsurface-flow patterns of ground-water contamination. These methods can be verified with surface geophysical techniques.

\section{Transition-Zone Studies}

There have been some initial tests of the hypothesis that the transition zone is a principal conduit of ground-water movement and groundwater contamination. Daniel was the first investigator to focus on the transition zone and has done some initial test drilling, well construction, and well logging to define its characteristics. In particular, temperature logs run in several wells located in Cary and in Guilford County, North 
Carolina, may be used to identify greater movement of water within the transition zone (Daniel and Sharpless, 1983).

Borehole geophysical $\mathrm{log}$ data were collected in June 1983 from five bedrock we11s (Gu-382, Gu-383, Gu-385, Gu-386, Gu-387) located at a test site (fig. 8) in the Greensboro-High Point Regional Airport area by Daniel and Sharpless (1983). Well depths ranged from 200 feet to 275 feet. The borehole geophysical data from these five wells were collected in order to refine current knowledge of subsurface geology and hydrologic parameters in the test-site area. The data collected included natural gamma-ray logs, porosity logs, temperature logs, televiewer logs, and caliper logs.

Temperature logs also were collected at all five well sites in March 1985.

Well-log data collected at the test site agree with the results of other well-log studies conducted in other sections of the Piedmont (Stewart, 1962). The bulk of the material in the upper 40 and 50 feet penetrated by these wells is unconsolidated regolith. Here, total porosities are as high as 60 percent and generally decrease significantly below this depth. The gamma ray logs identified most clay-rich zones in the saprolite, as well as zones of feldspars and micaceous minerals in bedrock. The temperature logs were evaluated in order to (1) obtain geothermal-gradient profiles in the bedrock wells, and (2) determine to what extent temperature profiles in an open borehole might delineate zones of ground-water entrance or movement. Nutter and Otton (1969) conducted a similar evaluation of temperature logs collected from wells located in the Maryland Piedmont detecting seasonal effects of temperature change on ground water in the first 60 feet below land surface.

The upper segments of temperature profile logs collected at well Gu-383 at the Greensboro-High Point test site in June 1983 and in March 1985 are shown in figure 12. Note the pronounced cool-water temperature bulge in June 1983 from 21 to 52 feet.

Only a slight cool-water temperature deflections were detected on temperature logs collected in March 1985 (fig. 12). Initial comparisons of recorded surface-water temperature data collected in North Carolina for the winter of 1982-83 (Gunter and others, 1984) and for the winter of 1984-85 indicate that the winter of 1982-83 may have been slightly cooler than the winter of 1984-85. The temperature profile in figure 12 may suggest that 
warmer water recharged the ground-water system in 1985 than in 1983 due to slightly milder winter conditions. It is interesting to note that the uppermost portions of the temperature curves ( 0 to 20 feet) have opposite slopes. These near-surface temperature curves may reflect the actual surface temperature conditions present when the logs were collected.

June 1983

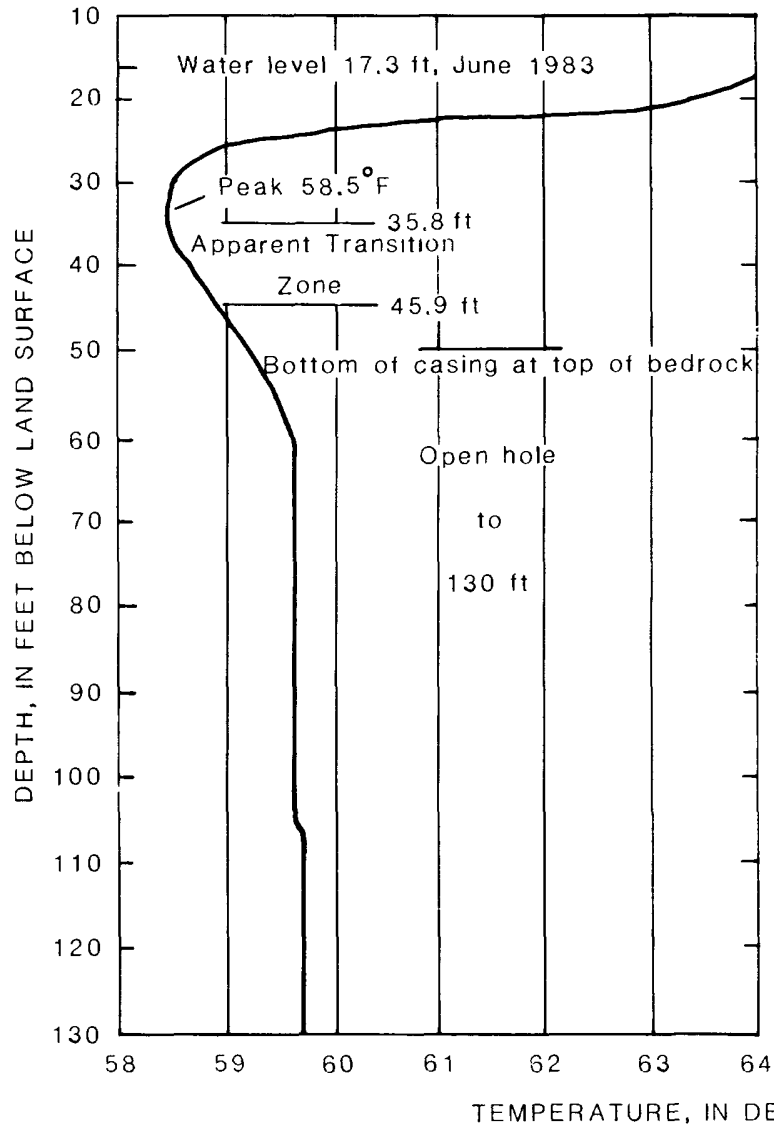

March 1985

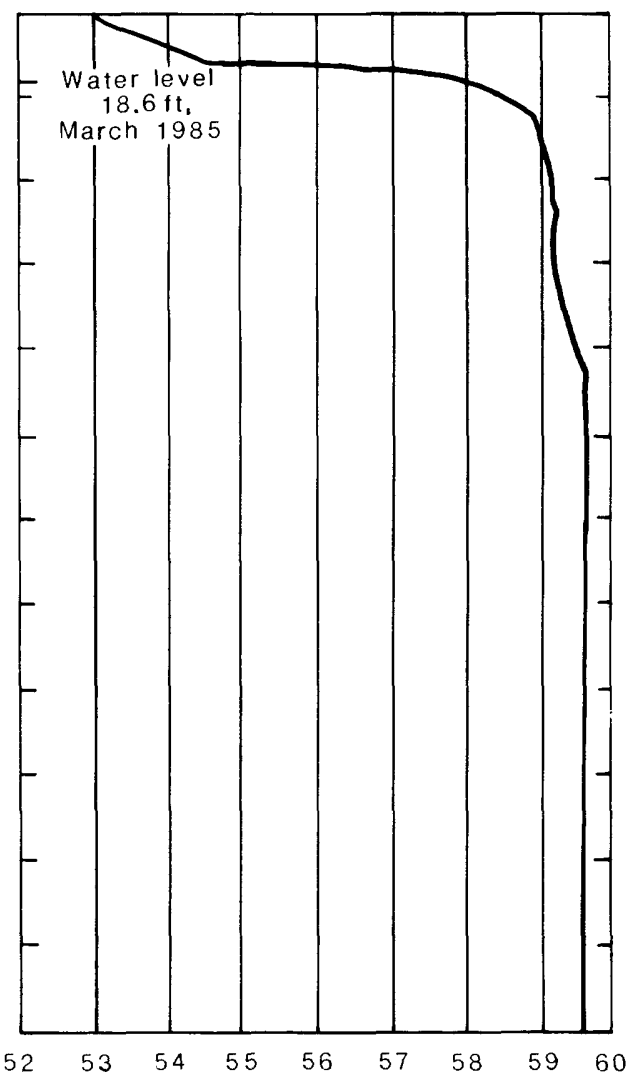

Figure 12.--Temperature logs for well Gu-383, June 1983 and March 1985, located at the Greensboro-High Point Regional Airport.

A more complete data base is needed in the Piedmont province in order to determine to what extent seasonal variations do affect ground-water temperatures and if the subsurface temperatures can provide evidence of greater flow in the transition zone than in the other zones.

\section{POTENTIAL SOURCES OF GROUND-WATER CONTAMINATION}

Assessment of potential sources of contamination is fundamental to the management of the ground-water resource. As part of this assessment 
process, Mew (1985) has developed a ranking system to evaluate ground-water contamination sources and has evaluated the NRCD's inventory of sources that has been compiled over the last 10 years. This inventory includes data on ownership, location, type of operation, type of waste, type of disposal facility or source, status of the source, monitoring, confirmation of ground-water contamination, data-base cross references, and regulatory history.

The waste-source inventory identified over 3,000 potential sources of ground-water contamination in North Carolina. Contamination has been verified at 240 of these sites. A subset of 592 sources from the inventory, containing only the confirmed contamination sources, the highest ranked sources, and the monitored sources was examined by Mew (1985). Two hundred and fifty-one of these sources are located in the Piedmont. Percentages of potential and confirmed sources of ground-water contamination by type for these 251 sources are shown in figure 13. Landfills, waste lagoons, and underground tanks make up most of the sources of ground-water contamination of concern.

The 1983 annual report of hazardous waste (North Carolina Department of Human Resources, Division of Health Services, 1984) states that within the State of North Carolina there were 618 facilities, each of which generated 2,200 pounds or more per month of hazardous waste. In addition, 111 facilities either treated, stored, or disposed of 2,200 pounds or more of hazardous waste. The majority of the waste generators and the waste handlers are in the Piedmont counties with Mecklenburg County (fig. 1) having the greatest number (86).

\section{WATER-QUALITY DATA BASE}

One of the principal objectives of this study has been to construct a data set containing the available data on ground-water quality in the Piedmont of North Carolina. Well locations of the combined data set are shown in figure 14 .

The data set constructed during this reconnaissance study provides a strong base for current and future ground-water quality study. The construction, editing, and analysis of information contained in this data 


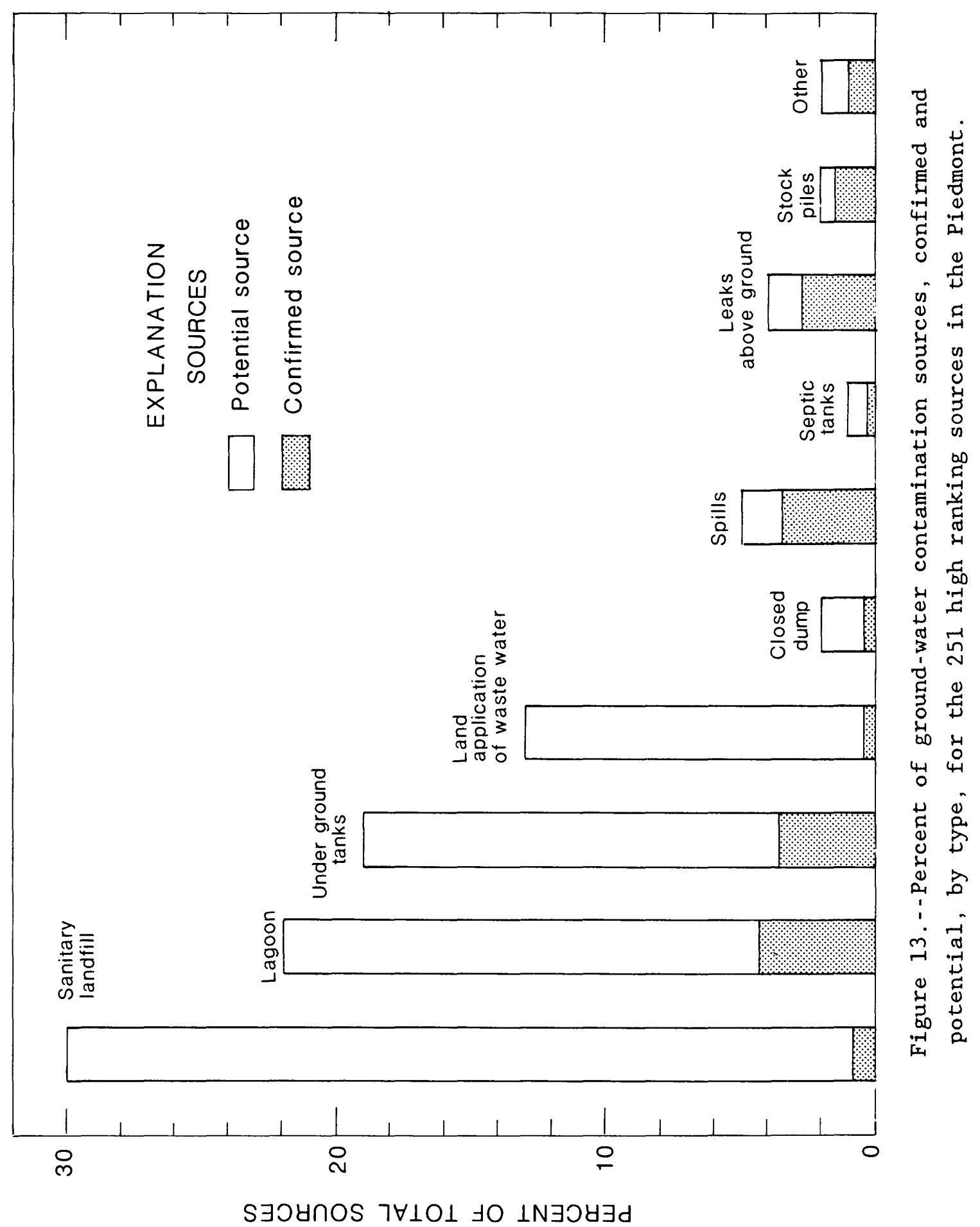




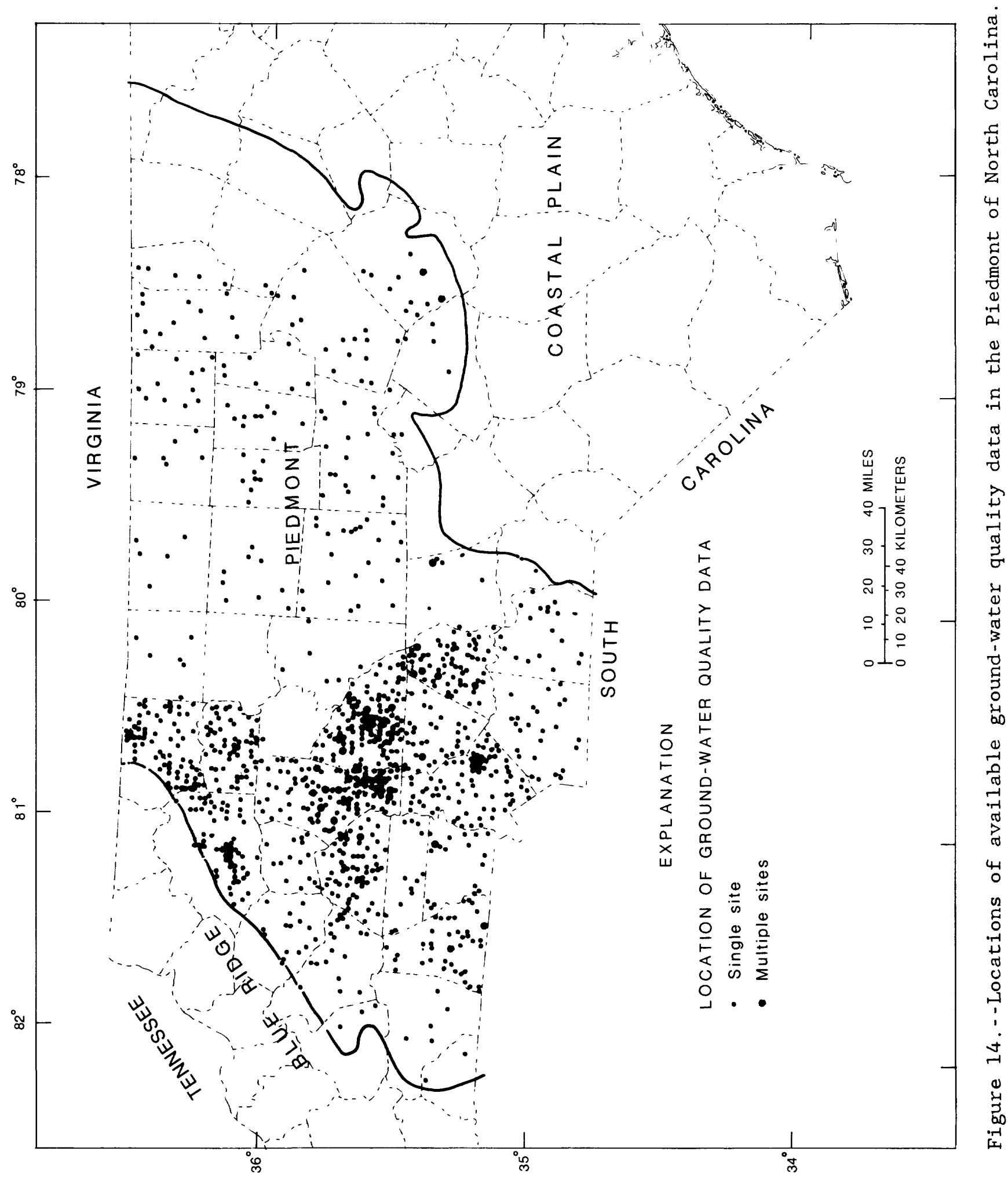


set is an ongoing process, and much additional work can be done to enhance its usefulness. Data on organic constituents and more trace-element data need to be collected and added to the data set.

Two principal sources of data form the bulk of the Piedmont groundwater-quality data set. The primary source is historical data, collected mainly during U.S. Geological Survey cooperative studies and published in numerous publications of the NRCD and preceding agencies. A map showing the coverage of the Piedmont province by these reports is shown in figure 15 . Another important source of data has been unpublished results of groundwater analyses made for the U.S. Environmental Protection Agency (EPA) 208 Planning Study of 1978-80 (208 Study). The 208 Study, which was directed by NRCD, produced laboratory analyses of shallow ground-water quality at nearly 600 sites. The recently initiated NRCD baseline water-quality network (Perry Nelson, North Carolina Department of Natural Resources and Community Development, written commun., 1985) is an important source of information for background water quality. Data from this ongoing study will also be added to the data set.

Data from recent and ongoing U.S. Geological Survey studies are an important part of information currently available on ground water in the Piedmont. Recent U.S. Geological Survey studies provide one of the few sources of analyses of constituents such as heavy metals and organics, but even this source is limited to only a few land-use types. One U.S. Geological Survey study in particular, the city of Charlotte and Mecklenburg County urban hydrology study (Eddins and Crawford, 1984), has been instrumental to site selection. It provides detailed information on countywide water quality of streams during low-flow periods.

The ongoing U.S. Geological Survey study of Charlotte-Mecklenburg County urban hydrology includes quarterly sampling of 24 monitoring wells in landfills around Charlotte, 10 privately-owned wells near the landfills, and streams draining landfill and residential areas.

Simmons and Heath (1979) examined baseline water quality from undeveloped basins all around North Carolina at both high and low flows. Low-flow data from this study can be used as an indicator of ground-water quality in undeveloped areas. 


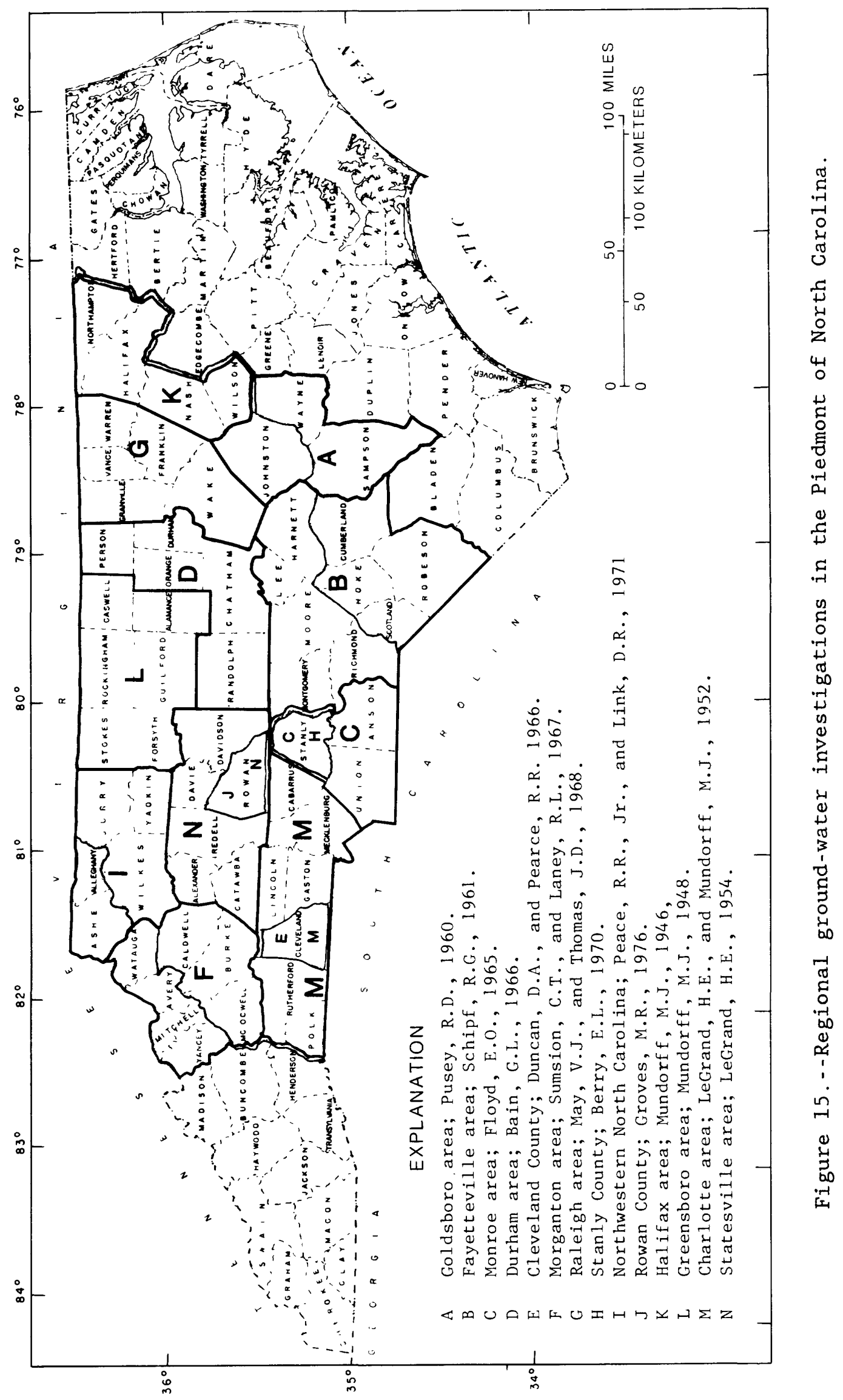


A study of the ground-water development potential in the Piedmont and Blue Ridge areas of North Carolina is the source of the geologic data used in correlation analysis with ground-water quality data, as well as much hydrologic framework information used in this study.

An ongoing U.S. Geological Survey study of the effects of landmanagement practices on sediment and chemical transport via streams in Guilford County, North Carolina, includes an examination of soil-water and ground-water quality in a tobacco-growing area.

\section{DATA ANALYSIS}

The data-analysis objective of the current study is to test the set of available ground-water quality data for relations between water quality and land use, geology, and soil characteristics. This was done using simple non-parametric analysis of variance (ANOVA) on the ranks of the data. In addition, some characterization of the data set is appropriate. However, a more complete description and analysis of the data is reserved for future study.

The data collected for the 208 study was used for this study because the water samples were collected over a period of 3 years and analyzed at the same laboratory, and the land uses associated with the sampling sites were known. This data set is well suited for testing by ANOVA, because the effect of uncontrollable variance due to analyses at different laboratories at different periods of time is not a factor.

The 402 we1ls included in the 208 study were quite shallow, with a mean depth of 27.7 feet. Daniel (1985) reports that in his survey of the North Carolina Piedmont and Blue Ridge the mean well depth for 5,221 wells is 154.0 feet, and the mean for 4,408 domestic wells is 123.6 feet. The Blue Ridge area has a similar hydrogeologic flow system to the Piedmont; therefore, wells from the Blue Ridge should not substantially differ in well characteristics from Piedmont wells. The 208 Study we1ls were augered in the regolith deep enough to obtain a water sample from just below the water table. The mean depth of the water table is 18.2 feet below land surface for the 208 Study. Daniel reports that the overall Piedmont and Blue Ridge mean water level in water-supply wells is 32.3 feet below land surface $(\mathrm{n}=$ 
$2,825)$. Water-supply wells used in Daniel's study tended to be deeper than the shallow 208 Study wells and generally had water-levels lower than those in shallow wells nearby. This indicates that in much of the area there is a downward gradient from the shallow part of the system to the deeper fractured rock system.

\section{Water-Quality Data}

An analysis of available ground-water quality data indicates that shallow ground water in the Piedmont generally is a slightly acidic (median $\mathrm{pH}, 6.5)$ sodium bicarbonate-type water with dissolved solids concentrations less than 100 milligrams per liter $(\mathrm{mg} / \mathrm{L})$. However, the water-quality data base contains analyses of contaminated as well as natural ground waters. Dissolved solids concentrations exceed $500 \mathrm{mg} / \mathrm{L}$ in a number of the analyses and exceed $1,000 \mathrm{mg} / \mathrm{L}$ in a few. Values of $\mathrm{pH}$ ranged from less than 2.0 units to as high as 10.8 units. Those samples with high dissolved-solids concentrations and extreme $\mathrm{pH}$ values were generally from wells in urban and industrial areas where the ground water has been contaminated.

Frequency histograms for $\mathrm{pH}$, alkalinity, specific conductance, and dissolved solids concentrations in ground waters in the Piedmont are shown in figures 16-19. The histogram for $\mathrm{pH}$ is bell-shaped with most values falling between a $\mathrm{pH}$ of 5.5 and 7.5. Histograms for alkalinity, specific conductance, and dissolved solids are more log normal in shape with most values of alkalinity (as $\mathrm{CaCO}_{3}$ ) less than $60 \mathrm{mg} / \mathrm{L}$, most specific conductance values less than 200 microsiemens, and most dissolved solids concentrations less than $100 \mathrm{mg} / \mathrm{L}$.

\section{Independent Variables}

Three different variables that may influence ground-water quality have been included in the data set: land use, geology, and soil type. The principal variable of interest in this study is land use. However, in defining the influences of land use on ground-water quality, it is important to account for the effects of other variables which may complicate analysis. Therefore, the variables of geology and soils have been added to the data set. 


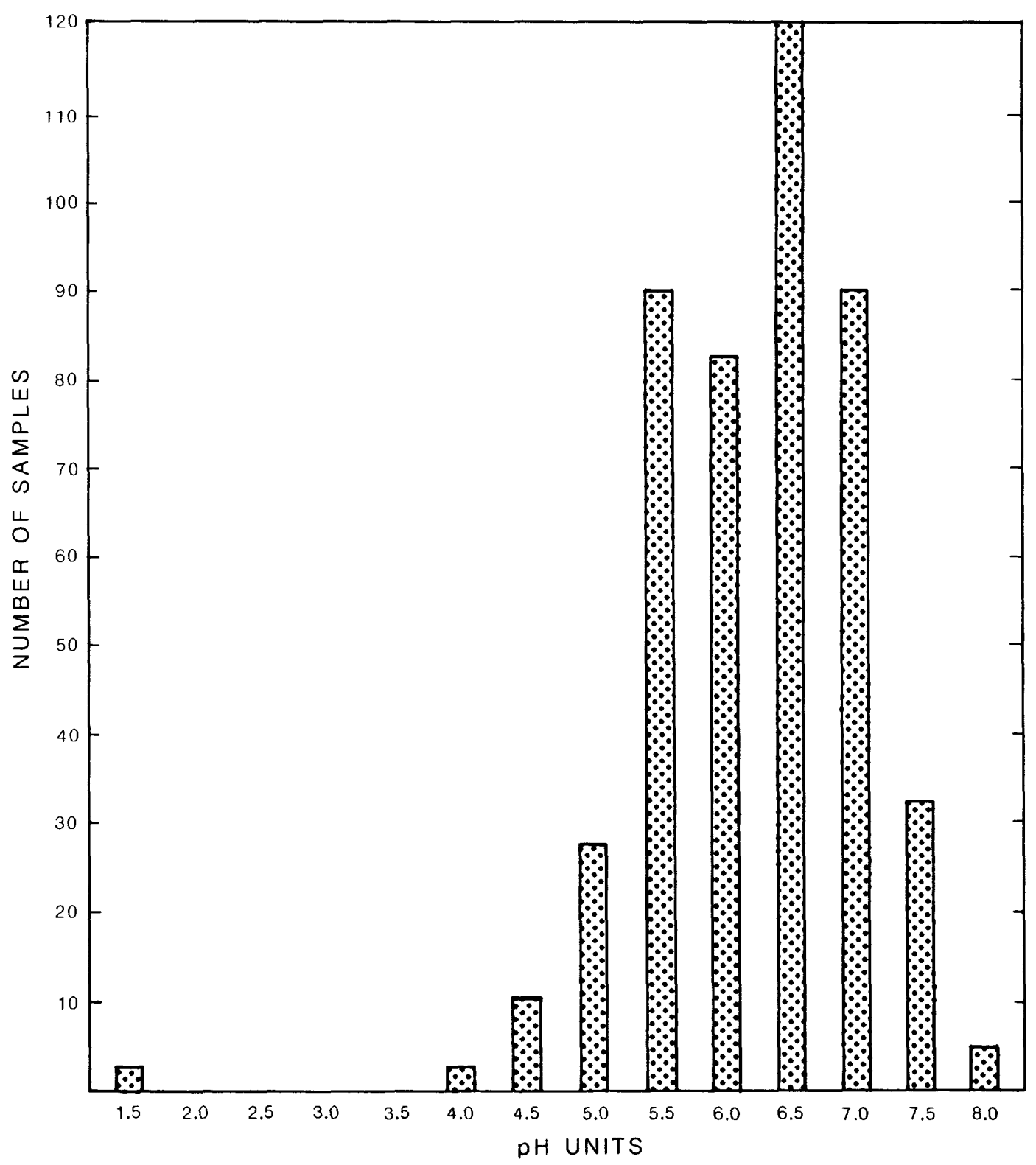

Figure 16.--A frequency histogram for $\mathrm{pH}$.

Land use is represented in the data set in two forms. The Land-Use Data Analysis (LUDA) land-use type (Anderson and others, 1976) and the 208 Study land-use type have both been entered for each well location. The different categorizations of land uses produce two distinctly different ways of sorting the data set.

Bedrock geology, as compiled by Daniel (1987), was used in defining the rock type for each well. Most of the wells are located in regions of the metavolcanic and metaigneous rock types. 


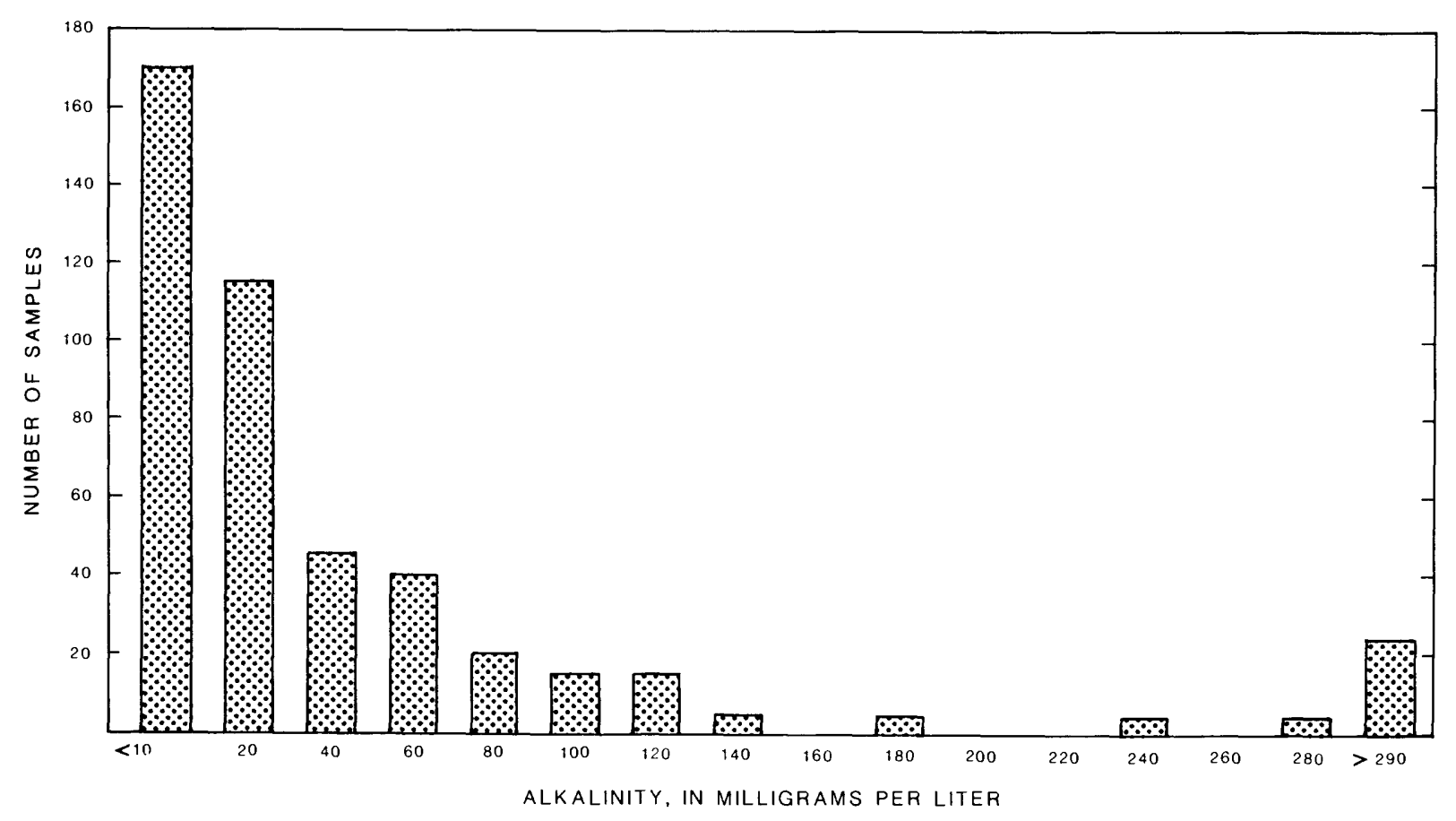

Figure 17.--A frequency histogram for alkalinity.

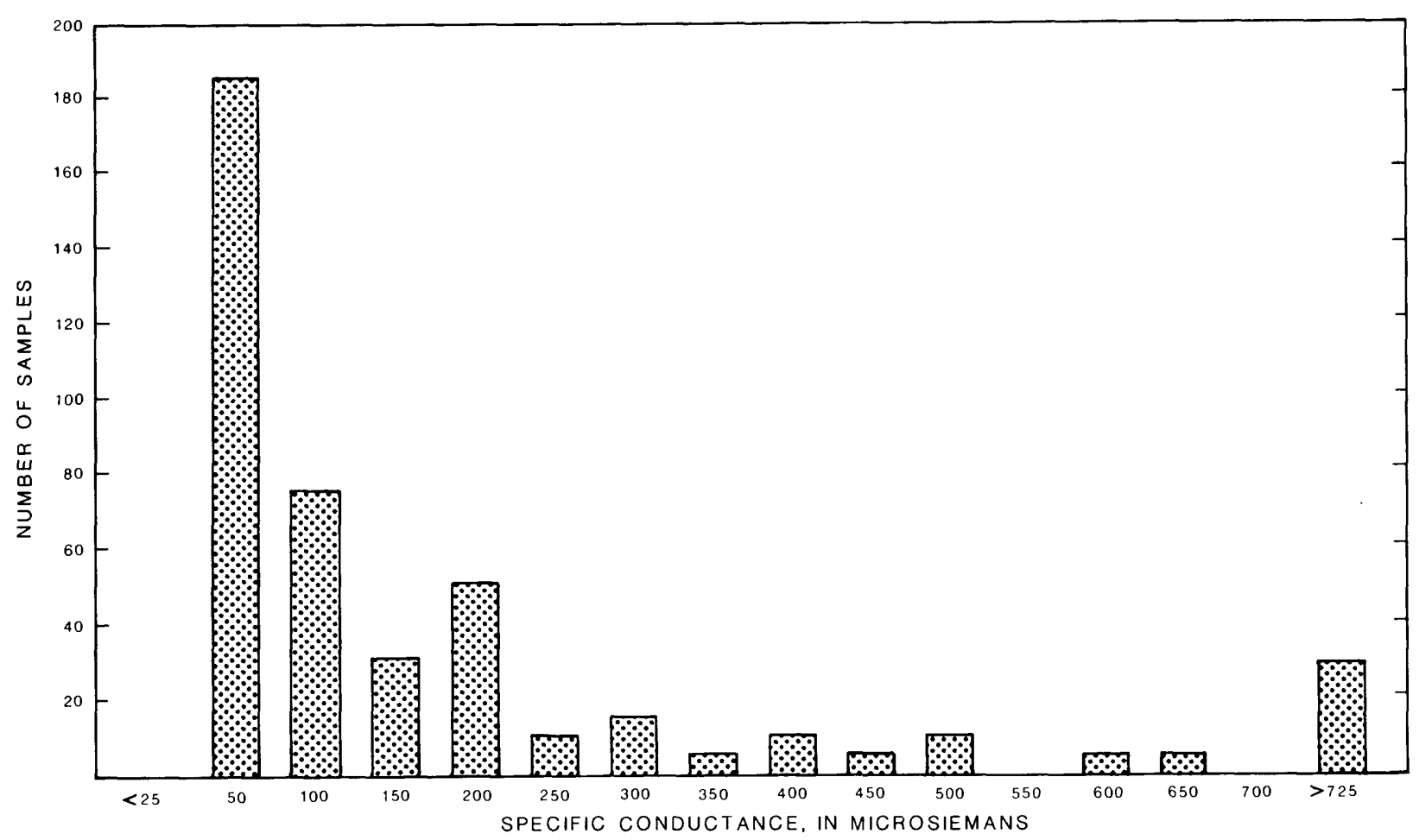

Figure 18.--A frequency histogram for specific conductance. 


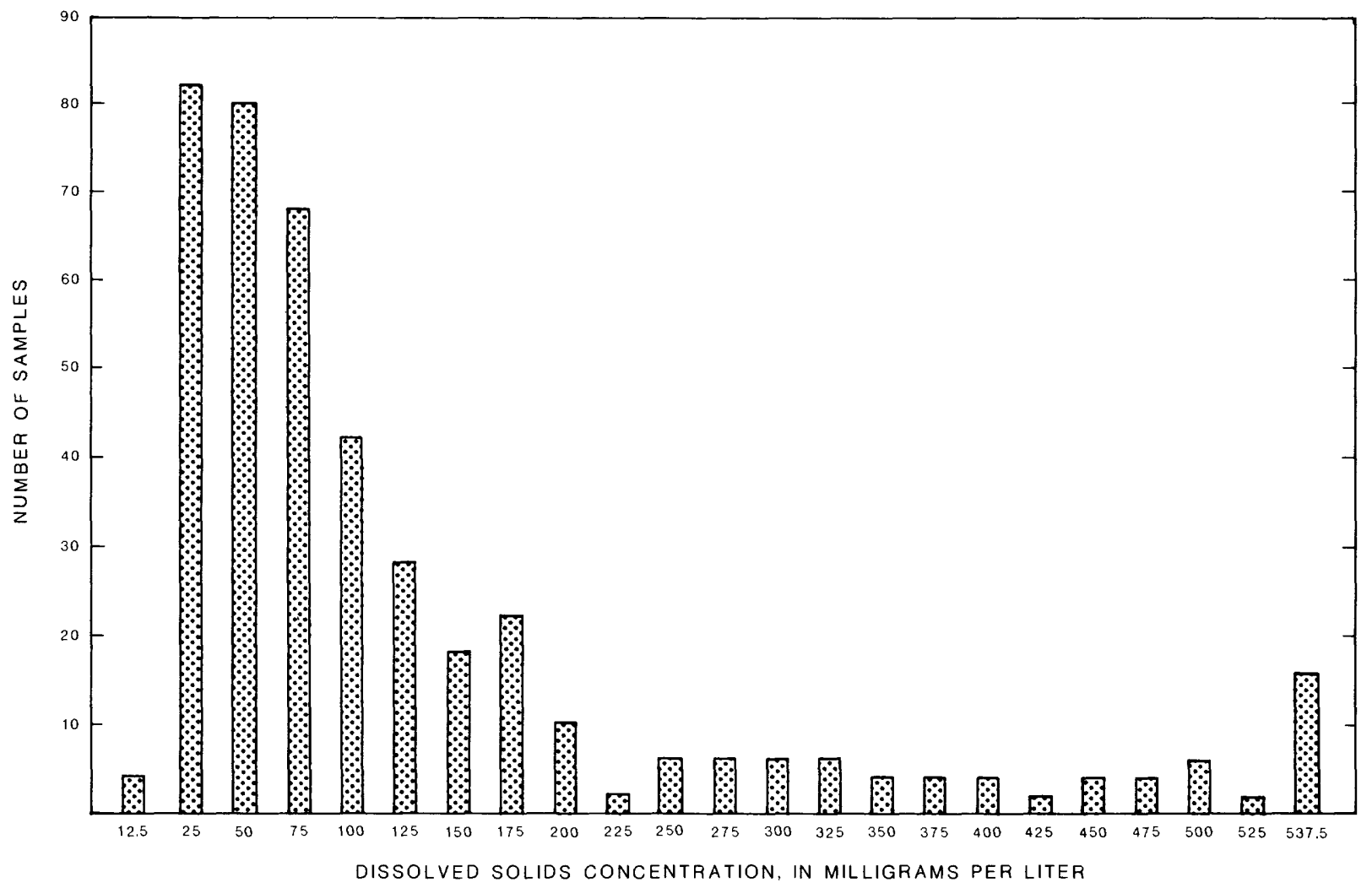

Figure 19.--A frequency histogram for dissolved-solids concentration.

Soil type at each well location was determined using the U.S. Soil Conservation Service (1978) soil classification system. The variables of soil type and rock type are not completely independent of each other since soils are usually derived from the underlying parent rock. However, in this analysis, soils and geology have been treated as separate variables simply to test if they affect ground-water quality.

\section{Analysis of Variance}

Non-parametric analysis of variance (ANOVA) on ranked data is used in this investigation to help define the relation between land use and groundwater quality. Helsel and Ragone (1984) describe the application of analysis of variance in the frame of reference of the U.S. Geological Survey ground-water quality appraisal program. Basically, one factor nonparametric ANOVA is a test for the comparison of means of the ranks of the concentrations. In other words, are the differences in the means of the 
concentrations of constituents in water due to chance variation alone, or are they the result of land use?

To test the null hypothesis that the means do not vary because of the effects of 1 and use, the ratio:

$$
F=\frac{\text { (Total variance) }- \text { (Within land-use region variance) }}{\text { (Within land-use region variance) }}
$$

is calculated and compared to the $F$ ratio that would be expected if the null hypothesis were true. If probability (PR) is low, then the effect investigated (land use, etc.) is significant, and the null hypothesis is rejected.

The results of analysis of variance of the water-quality constituents and the four independent variables are shown in table 2. Many of the $F$ statistic values shown in table 2 for all the independent variables are significantly larger than the $F$ values that might be produced by chance alone. In other words, for many of the water-quality constituents, the null hypothesis is rejected, land use, geology, and soil type do indeed influence ground-water quality for many constituents.

Simple analysis of variance has shown that there is at least one subgroup mean for land use, geology, and soils that has a variance significantly different from the variance that might be expected from chance. The next step is to find out which of the subgroup ranked means tested are significantly different from one another. One technique that can be used to show the subgroups that are significantly different from the others is the Duncan multiple-range test (Duncan, 1955).

The Duncan procedure sorts the subgroup means into groups that are statistically different from one another. When applied to the land use, geology, and soils classifications for this study, the Duncan analysis produced up to 4 out of 20 groups of different soil types, 3 out of 4 for the 208 study land use, 3 out of the 15 LUDA classes of land use categories, and up to 4 groups of rock types that were found to be statistically different from one another out of 14 rock types. In other words, the test indicated that, in future analyses, combining of some of the land use, geology, and soils catagories may be appropriate. The results of the Duncan 


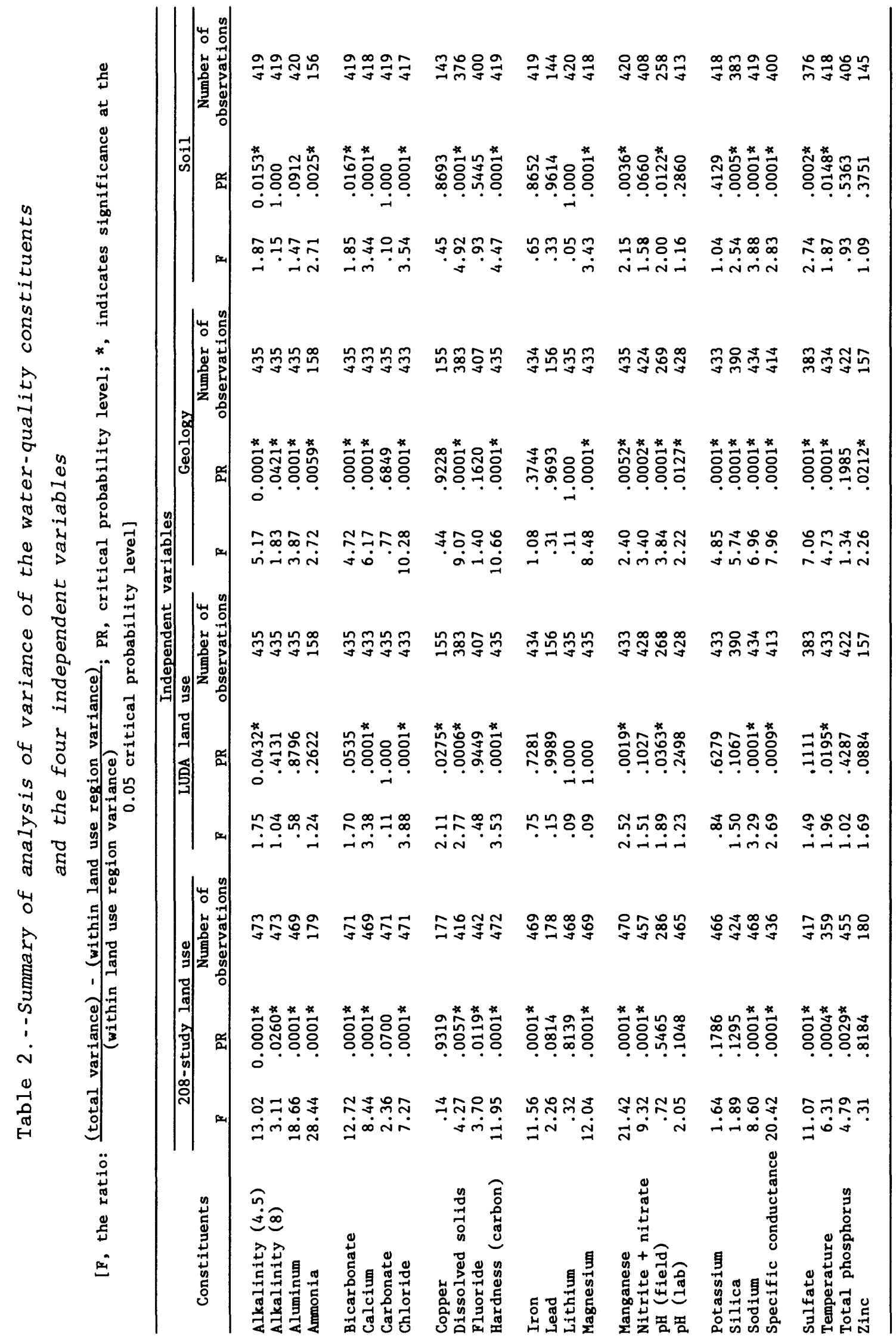


test suggest that the separate LUDA categories for urban areas could be grouped together. The 208 Study land-use data fared a little better, showing more separation of the subgroups than the LUDA data.

The ANOVA results shown in table 2 used 208 study data land-use classifications of industrial, mixed urban, residential, and undeveloped. A finer division of these land-use classes into 17 categories produced similar results to the grouped classes with up to 4 Duncan groupings. The industrial land-use category was associated with the highest constituent concentrations followed generally by the mixed urban, residential and undeveloped land-use categories. Definition of the land-use catagories for the 208 study data was based on information on the we11 locations. Therefore, a quantitative breakdown of the exact land uses represented by each of the classifications or categories is not possible. The industrial land use includes waste-water treatment plants, landfills, and manufacturing plants. The mixed-urban category includes a potpourri of commercial, retail, and urban land uses. The residential category includes both high and low density housing areas. The undeveloped land-use classification includes forests, fields, cropland, and farms.

A more detailed analysis of the data set is reserved for future study. As the current set of data is supplemented with organic constituents and more trace-element data, the information that can be gleaned from the data set by statistical analysis will increase.

\section{NEED FOR ADDITIONAL STUDY}

One of the principal objectives of this study has been to design a ground-water sampling program to test the relation between ground-water quality and land use. Definition of the relation of ground-water quality to land use will allow extrapolation of the data to a larger scale, giving an overall projection of ground-water quality within the Piedmont province based on land use.

The assembly of available information about the flow system and groundwater quality has led to the formulation of the following hypotheses about the system. 
1. Land use.--Different land-use types are associated with different ground-water chemistry characteristics. The amount of ground-water contamination in the regolith and bedrock-fracture system is related to each land-use type. These relations can be mathematically defined to a level that allows statistical prediction and numerical modeling.

2. Contaminant-flow system.--The transition zone between bedrock and regolith serves as a primary transmitter of ground water and contaminated ground water. The regolith serves as the principal reservoir of contaminated ground water.

a. Attenuation of ground-water contaminants in the regolith is related to the degree of weathering and composition of regolith material.

b. The velocity of contaminant movement can be highest within the fractured-bedrock system, particularly under stressed conditions.

c. The deeper zones in basement rock generally contain the best quality water in the system due to contaminant attenuation in the regolith and shallow fractures.

d. Geomorphological analysis can be used to find fracture zones that help predict general subsurface-flow patterns of ground-water contamination. These methods can be verified with geophysical techniques.

3. Natural ground-water quality.--Ground-water quality is related to soil type and geology. Identification of measurable soil and geological characteristics that affect ground-water quality will allow a better characterization of the relation of 1 and use to water quality.

\section{Network Design}

A ground-water quality monitoring network designed to test these hypotheses can provide: 
1. Detailed information that can be used to refine understanding of the flow system;

2. Data that can give a regional picture of the effects of land use on water quality.

A hypothetical drainage basin (LeGrand, 1984) with multiplecontamination sources (fig. 20) illustrates the complexity of sampling to determine ground-water quality on an areal basis. The ground-water contamination from point sources such as spills and small waste lagoons is generally local and detectable only if wells are placed near the source and in the contaminant plume. Contamination from nonpoint sources, however, such as application of pesticides to farm fields, may be areal in extent but locally dilute and difficult to detect in any particular well.

Helsel and Ragone (1984) provide guidelines for experimental design within the framework of the U.S. Geological Survey national program of ground-water quality assessment. These guidelines stress the importance of:

1. Representative sampling of study areas to give a characterization of overall basin ground-water quality. In this respect, large localized sources such as landfills within the study area should be described separately, possibly by a separate monitoring program.

2. Random sampling to reduce error in statistical testing of the data. After a group of wells has been located within the study area to give representative hydrologic and geochemical coverage of the area, these wells should be randomly sampled to reduce bias in the data from any one particular well or series of wells.

3. Maximization of the ability to detect effects given a limited number of samples. The principal effect of interest is the influence of land use on water quality. Given a number of regions of different land uses, we wish to find:

a. If there are significant water-quality differences between the land uses; 

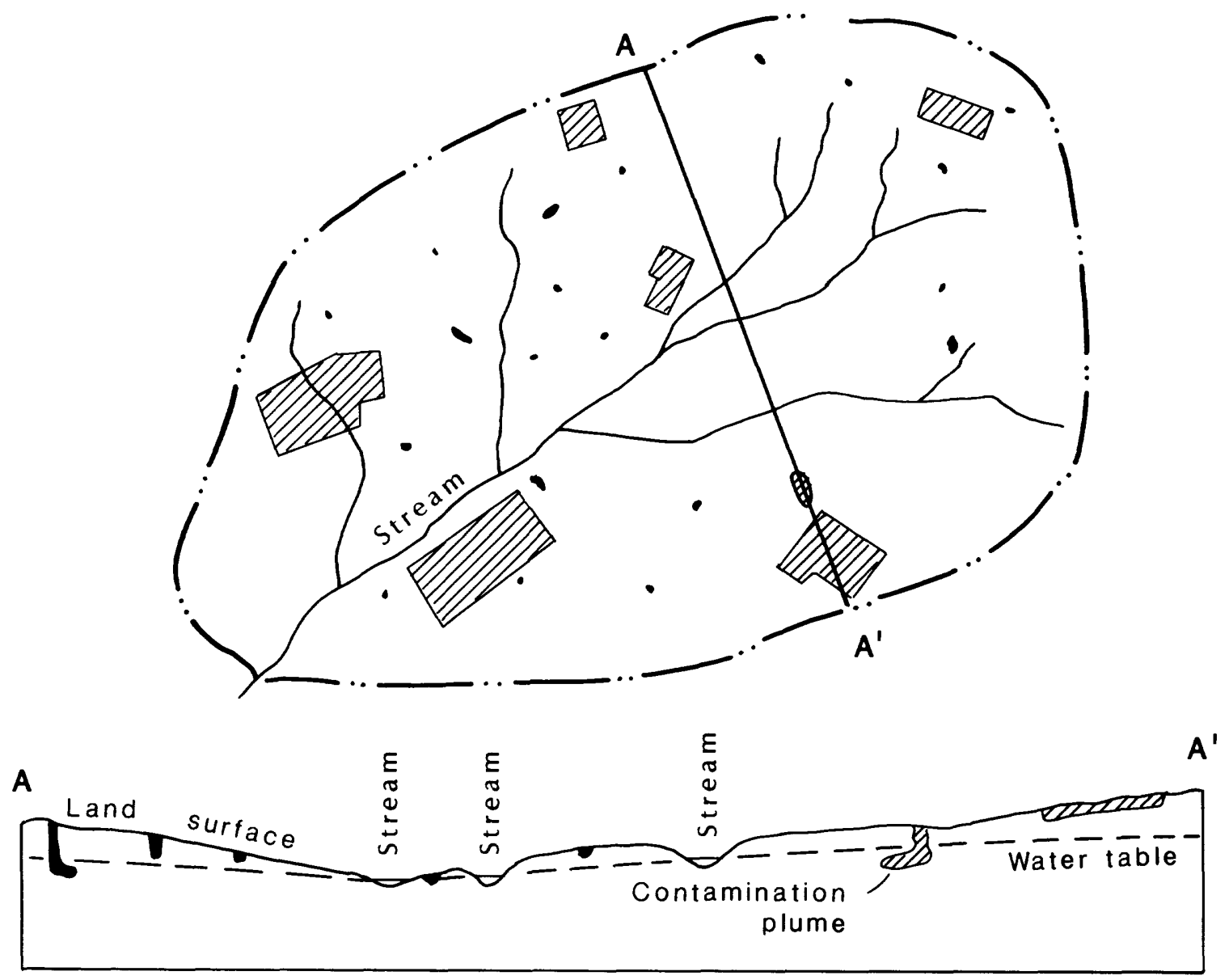

Note:. Not to scale

EXPLANATION

- Point source of contamination

QDIIJ Non-point source of contamination

A $A^{\prime}$

Line of section

- - B Basin boundary

Figure 20.--A hypothetical drainage basin with multiple contamination sources (after LeGrand, 1984).

b. If there are significant areal variations in water quality in any particular land use (Significant variance between wells may obscure detection of differences between land uses. Additional sampling may improve definition of this variance); and 
c. If there is significant variation over time in water quality in samples from any one well. (Significant variance between samples from a single well may obscure detection of differences between land uses. Additional sampling may improve definition of this variance.)

Once estimates for variance in concentrations between wells and variance of concentrations in the same well are known, the number of wells needed per area and the number of samples needed per well can be optimized for a given cost and number of study areas (Sokal and Rohlf, 1969; Helsel and Ragone, 1984).

\section{Data Collection}

To test the land-use and contaminant flow-system hypotheses, additional information about ground-water quality will need to be collected. In addition, special studies are needed to further refine the conceptual model of the hydrologic framework. As part of the study design, monitoring of (1) four different areas representing old industrial, new industrial, mixed urban, and residential land uses in Mecklenburg County, (2) an agricultural land-use area in Guilford County, and (3) two other sites to refine the framework are planned.

The monitoring will consist of three principal sampling programs:

1. Sampling of existing wells in and outside of the principal study areas;

2. Sampling from wells constructed specifically for the sampling program within the principal study areas; and

3. Sampling of baseflow of streams within the study areas.

There is very little information in available data bases about wells in and near the study areas. One of the first tasks of the study will be to identify the wells within the area that can be sampled. It is likely that few of these wells will be usable in the monitoring network. Domestic water-supply wells are usually cased to the fractured rock, bypassing the zones hypothesized to be most susceptible to ground-water contamination. 
Usable sampling wells will be supplemented with new wells constructed specifically for this study. The goal will be to establish a network of wells which sample areas representative of particular land uses. Each well will sample a cell in the geohydrologic system. The locations of these cells will generally be in downgradient areas of the land uses under study. Wells will be installed to sample the upper part of the saturated regolith and the transition zone.

The resultant network of wells will be sampled during an initial sampling period to define spacial water-quality variability related to land use. Sampling wells open to different zones and multiple sampling in individual wells will be used to estimate within-well variability.

After the initial period of sampling, smaller groups of wells will be randomly selected from the group of wells sampling the shallow zones, the group sampling the transition zone, and the group sampling the deeper zone. Each of these three subgroups of wells will then be sampled periodically so that water-quality variation over time may be defined.

Sampling of streams during baseflow periods in basins and subbasins within the study areas will accompany sampling of wells. The sampling intervals will be nonuniform, depending on the streamflow conditions at the time of scheduled well-sampling trips.

\section{Sampling Methods}

The complexity of sampling to determine ground-water quality on a regional basis is further complicated by the difficulty of correctly measuring substances such as metals or organic substances in extremely low concentrations in the ground-water system. Wells within the network need to be designed to allow sampling of the desired zones without contamination from other zones or the casing materials. The sampling protocol will consider such factors as: sampling frequency, well diameter, sampling device used, amount of water to be removed from the well before sample collection, depth in water column that the sample is taken, bottle types and composition, sample filtering in the field, movement of sample from sampling device to the sample bottle, sample preservation, time limits required on delivery of samples to the laboratory, and quality control (Nacht, 1983). 
In the initial assessment of water quality in a study area it is necessary to define which contaminants are present in the system in measurable amounts. Laboratory analyses of major inorganic constituents and nutrients combined with hydrocarbon and trace-element scans will be used to define the suite of constituents to be tested for in the following period of periodic sampling. Due to the high cost of sample analysis for organic constituents and trace metals, the assessment will begin with a relatively inexpensive scan or semi-qualitative method that indicates if contaminants are present (Helsel and Ragone, 1984). One such technique, the gas chromatograph-flame ionization detector (GC-FID) scan, is designed to detect the presence of hydrocarbons. Another technique, neutron-activation analysis (NAA), is a low-cost method that measures concentrations of a suite of elements, including many trace metals, and has very low detection limits for these elements.

During a GC-FID scan, the gas chromatograph separates organic compounds within the sample, delivering a stream of components of the sample to the flame-ionization detector (F. Cardinali, U.S. Geological Survey, oral commun., 1985). The sample stream comes out of the gas chromatograph and goes into a hydrogen flame, where the organic compounds are burned, producing ions and a current flow that is proportional to the amount of organic chemical present. This current can be detected and displayed. Standards and blanks are run to allow comparison and detection of laboratory contamination.

Careful comparative examination of the chromatographs of the series of samples, standards, and blanks may indicate that organic substances are in the sample that may warrant further investigation. The GC-FID scan can detect organic compounds, and in particular hydrocarbons, at levels of 0.5 micrograms per liter. GC-FID scans have been used in this study during the process of site selection. The technique will provide a means in the proposed monitoring studies of screening samples prior to substance-specific analysis.

In NAA, the sample is first irradiated by neutrons in a nuclear reactor (Kimberley and Bellis, 1985). The slightly radioactive sample produces gamma rays for each decaying radioisotope which can be detected. The rate of production of gamma rays for each induced radioisotope is proportional to its concentration. Spectral analysis is necessary in this analysis. 
The elemental analysis produced by a complete NAA scan includes a variety of trace elements rarely tested for in traditional atomic-absorption spectrophotometry. These rare elements can individually be indicators of contamination or, in combination, can provide a signature that may be used to characterize ground water at a study location. Concentrations of 43 different elements are measured in a complete NAA scan.

Gas chromatograph-flame ionization detector and NAA scans provide a means to help define the suite of constituents to be tested for in later sampling. These scans, combined with laboratory analyses of major inorganic constituents and nutrients, will be useful in determining what constituents need to be tested for in the following period of random sampling.

\section{Special Studies}

The special-study program is designed primarily to test the principal hypothesis of the study that levels of ground-water contamination can be related to land use. However, to address the hypotheses about the contaminant-flow system, and especially the role of the transition zone in that system, a few additional special studies are proposed. These studies tie into other current U.S. Geological survey research.

The distribution of solutes within the ground-water system is three dimensional. A vertical definition of water-quality variation within the ground-water flow system is necessary to describe solute distribution within the flow system on a local scale and to understand regional or basin-wide contaminant movement. To study the vertical variation in water quality in the regolith fractured-rock system, a nest of wells, each with a short screen interval at different depths, can be installed in areas where there is known ground-water contamination. Sampling of these well-nest sites, coupled with careful identification of the nature of the regolith and fractured-rock system at a site, will test the hypothesis that the transition zone plays a particularly important role in the contaminant-flow system.

Temperature logs can be used to detect seasonal effects on ground-water temperatures in the shallower parts of a borehole and to indicate groundwater flow (Nutter and Otton, 1969). However, a more complete data base is needed in the Piedmont province in order to determine the extent seasonal 
variations affect near-surface ground-water temperatures and if the subsurface temperatures provide evidence of greater flow in the transition zone than the other zones. One possible approach would be to run temperature logs monthly over a 1 - to 2 -year span at an established test site with a known regolith-bedrock profile. Another approach is to place thermocouples in key boreholes at the test site to record ground-water temperatures at various borehole depths for various time periods. The goal is to obtain enough temperature-profile information to test the hypothesis that differential flow within the regolith and fractured-rock system affects ground-water temperature.

\section{SUMMARY AND CONCLUSIONS}

The objective of this study is to evaluate the quality of ground water in the combined regolith and fractured-rock ground-water system in the North Carolina piedmont and to develop and test hypotheses regarding the relationship of contamination to land use. This is a two-phase study. The first phase is the reconnaissance of available data and design of a monitoring program. The second phase is the implementation of that monitoring program and analysis of data from that program. This report documents of the progress of the first phase of the study.

The igneous and metamorphic rocks of the Piedmont are mantled by a cover of their own weathering products. The unweathered massive bedrock of about 400 feet below land surface grades upwards into fractured rock, then weathered rock with boulders of less weathered parent rock, followed by clay-rich saprolite (an unconsolidated material which contains remnant structure of the parent rock), and finally the soil horizons. In floodplains, streams rework the erodible material, sorting it into layered unconsolidated deposits. The mantle of weathered material, soil, and alluvium is generally called the regolith. In the Piedmont, the regolith is usually 30-60 feet thick. The regolith and underlying fractured rocks combine to make up a complex, multi-media flow system. The components of the system are:

1. The unsaturated zone in the regolith,

2. The saturated zone in the regolith,

3. The transition zone, and

4. The fractured-bedrock system. 
The saturated thickness in the regolith provides the bulk of the water storage within the Piedmont ground-water system. The regolith serves as a reservoir supplying water to interconnected fractures within the bedrock. At the base of the regolith there is generally a zone of weathered rock, boulders, and saprolite. This transition zone has high permeability relative to other zones, and it may create a high-flow zone within the ground-water flow system.

On a regional scale, prediction of the natural direction of groundwater flow can be related to surface topography. Since most of the natural flow is probably confined to the upper 30 feet of bedrock, where there are the most fractures, and the transition zone, the distance between the point where a drop of water or waste enters the system is commonly less than a half mile from where that drop may eventually discharge to a stream (LeGrand, 1958). The perennial-stream drainage basin is essentially a complete flow-system cell, similar to and yet generally separate from surrounding basins.

Available sources of data on ground-water quality in the Piedmont of North Carolina have been identified and are being combined into a data set which also includes data on regional characteristics of the Piedmont such as land use, soils, and geology. The bulk of the data currently in the data set was collected between 1978 and 1980 in a program of the North Carolina Department of Natural Resources and Community Development (NRCD). Historical data, published in numerous publications of the North Carolina Department of Natural Resources and preceding agencies, most of which were U.S. Geological Survey cooperative studies, are also a primary source of data for this study.

Available land-use data were obtained from LUDA land-use maps, from the Mecklenburg County Planning Department, and the 208 Study. About 65 percent of the North Carolina Piedmont land area is forest, about 25 percent is cropland, and about 6 percent is urban and residential.

Several current U.S. Geological Survey studies have provided valuable information during the first phase of the investigation. One study in particular, the Charlotte and Mecklenburg County study (Eddins and Crawford, 1984), has been instrumental in the selection of possible second-phase study 
sites and has provided detailed information on county-wide water quality of streams during baseflow periods.

The set of ground-water quality data constructed during this reconnaissance study provides a strong base for current and future groundwater quality study. The construction, editing, and analysis of information contained in this data set is an ongoing process. The data set contains over 1,800 water-quality observations. The wells included in the 208 study were shallow, with a mean depth of 27.7 feet. The mean depth of the water table was 18.2 feet below land surface for the 208 study.

Temperature and $\mathrm{pH}$ show bell-shaped normal distributions. The other water-quality constituents show distributions that appear to be log-normal in shape.

Three different variables that may influence ground-water quality have been included in the data set. The variables of land use, geology, and soil type are all likely to affect water quality. The principal variable of interest in this study is land use. However, in defining the influences of land use on ground-water quality, it is important to account for the effects of other variables which may complicate analyses. Therefore, the variables of geology and soils have been added to the data set.

Non-parametric analysis of variance of the water-quality data indicates that land use, soil type, and geology influence ground-water quality for many constituents. The results of the Duncan multiple-range test suggest that the separate LUDA catagories for urban areas could be grouped together.

These are the hypotheses which need to be tested by further study:

1. Land use.--The amount of ground-water contamination in the regolith and bedrock-fracture system is related to land use. Each land-use type may be characterized by a particular ground-water chemistry.

2. Contaminant-flow system.--

a. The transition zone between bedrock and regolith serves as a primary transmitter of contaminated 
ground water. The regolith serves as the principal reservoir of ground-water contamination.

b. Attenuation of ground-water contaminants is related to the degree of weathering and composition of regolith material and the hydraulic conductivity, gradient, and porosity of the material.

c. Ground-water contaminants generally move in the direction of ground-water flow and at various rates depending upon water solubility.

d. The deeper zones in basement rock generally contain the best quality water in the system due to contaminant attenuation in the regolith.

e. Geomorphological analysis can be used to identify fracture zones that help predict general subsurfaceflow patterns of ground-water contamination. These methods can be verified with surface geophysical techniques.

3. Natural ground-water quality.--Water quality is related to soil type and geology, and the relation can be quantified.

Future study is considered for four different land uses in Mecklenburg County, North Carolina. Drainage basins containing old industrial, new industrial, mixed urban, and residential land uses have been identified as potential study sites. Ground water from these basins will be collected from a network of wells augered to the top of the saturated zone and into the transition zone. Sampling wells open to different zones through the regolith and fractured rock system will test the hypothesis that the transition zone between the regolith and the fractured rock is a primary transmitter of contaminated ground water.

Gas chromatograph-flame ionization detector and NAA scans will be combined with selected laboratory analyses of volatile organic compounds and analyses of major inorganic constituents and nutrients in the initial period of sampling to define the suite of compounds to be tested for in the following period of random sampling. Sampling of baseflow of stream basins and subbasins within the study areas will accompany sampling of wells. The sampling intervals will be nonuniform, depending on the baseflow conditions at the time of scheduled well-sampling trips. 
The Mecklenburg County studies will be coupled with other ongoing U.S. Geological Survey studies in the Piedmont. A study of ground-water quality in Guilford County, North Carolina, will provide information about agricultural land uses. A study in Mecklenburg County relating land use to surface-water quality will provide additional detailed land-use information, as well as results relevant to the proposed ground-water study.

The data collected from the Mecklenburg and Guilford County studies will be combined with the set of available ground-water quality data and used to test for correlations between land use and ground-water quality. The hypothesis that land use can be used to estimate regional ground-water quality will be tested using non-parametric analysis of variance. Comparison of results to other areas with known water-quality characteristics will allow verification of the predictive models.

\section{REFERENCES}

Anderson, J.R., Hardy, E.E., Roach, J.T., and Witmer, R.E., 1976, A land use and land cover classification system for use with remote sensor data: U.S. Geological Survey Professional Paper 964, 28 p.

Bain, G.L., 1966, Geology and ground-water resources of the Durham area, North Carolina: North Carolina Department of Water Resources GroundWater Bulletin 7, 147 p.

Berry, E.L., 1970, Ground-water quality in Stanly County, North Carolina: North Carolina Department of Water and Air Resources Ground-Water Circular 15, $24 \mathrm{p}$.

Cressler, C.W., Thurmond, C.J., and Hester, W.G., 1983, Ground water in the greater Atlanta region, Georgia: Georgia Department of Natural Resources, U.S. Environmental Protection Agency, and The Georgia Geologic Survey, in cooperation with U.S. Geological Survey, Information Circular 63, 143 p.

Daniel, C.C., III, 1985, Statistical analysis of water-we11 records from the Piedmont and Blue Ridge of North Carolina: Implications for wellsite selection and well design (abs.), Geological Society of America Abstracts with Programs, v. 17, no. 2, p. 86-87. 1987, Statistical analysis relating well yield to construction practices and siting of wells in the Piedmont and Blue Ridge provinces of North Carolina: U.S. Geological Survey Water-Resources Investigations Report 86-4132, 54 p. 
Daniel, C.C., III, and Sharpless, N.B., 1983, Ground-water supply potential and procedures for well-site selection Upper Cape Fear River Basin, Cape Fear River Basin Study 1981-83: North Carolina Department of Natura1 Resources and Community Development and U.S. Water Resources Council in cooperation with U.S. Geological Survey, 73 p.

Daniels, R.B., Kleiss, H.J., Boul, S.W., Byrd, H.J., and Phillips, J.A., 1984, Soil systems in North Carolina: North Carolina Agricultural Research Service, North Carolina State University, Bulletin 467, 77 p. Duncan, D.B., 1955, Multiple range and multiple F tests: Biometrics, v. 11, p. $1-42$.

Duncan, D.A., and Peace, R.R., Jr., 1966, Ground-water resources of Cleveland County, North Carolina: North Carolina Department of Water Resources Ground-Water Bulletin 11, 65 p.

Eddins, W.H., and Crawford, J.K., 1984, Reconnaissance of water-quality characteristics of streams in the city of Charlotte and Mecklenburg County, North Carolina: U.S. Geological Survey Water-Resources Investigations Report 84-4308, $105 \mathrm{p}$.

Eder, B.K., Davis, J.M., and Robinson, P.J., 1983, Variations in monthly precipitation over North Carolina: North Carolina Climate Program Office, North Carolina State University, Raleigh, N. C., Report No. $185,50 \mathrm{p}$.

Farrar, S.S., 1985, Tectonic evolution of the easternmost Piedmont, North Carolina: Geological Society of America Bulletin, v. 96, p. 362-380.

Fenneman, N.M., 1938, Physiography of eastern United States: McGraw-Hill Book Co., New York, p. 121-123.

Floyd, E.0., 1965, Geology and ground-water resources of the Monroe area, North Carolina: North Carolina Department of Water Resources GroundWater Bulletin 5, 109 p.

Groves, M.R., 1976, Preliminary report on ground-water resources of Rowan County, North Carolina: North Carolina Department of Natural and Economic Resources Ground-Water Bulletin 22, 63 p.

Gunter, H.C., Hill, C.L., and Dillard, T.E., 1984, Water-resources data North Carolina, water year 1983: U.S. Geological Survey Water-Data Report NC-83-1, $534 \mathrm{p}$.

Harned, D.A., and Daniel, C.C., III, 1987, Ground-water component of Piedmont streams in Implications for ground-water supply systems and land-use planning: GSA Abstracts with Programs, v. 19, no. 2, February 1987. 
Heath, R.C., 1980, Basic elements of ground-water hydrology with reference to conditions in North Carolina: U.S. Geological Survey WaterResources Open-File Report 80-44, 856 p. 1983, Basic ground-water hydrology: U.S. Geological Survey WaterSupply Paper 2220, 84 p. 1984, Ground-water regions of the United States: U.S. Geological Survey Water-Supply Paper 2242, $78 \mathrm{p}$.

Heath, R.C., and Giese, G.L., 1980, What about ground water in western North Carolina: are large supplies feasible?: U.S. Geological Survey Pamphlet.

Helsel, D.R., and Ragone, S.E., 1984, A work plan for ground-water quality appraisals of the toxic-waste ground-water contamination program: U.S. Geological Survey Water-Resources Investigations Report 84-4217, 33 p.

Hem, J.D., 1970, Study and interpretation of the chemical characteristics of natural water, 2nd ed: U.S. Geological Survey Water-Supply Paper $1473,363 \mathrm{p}$.

Kimberley, M.M., and Bellis, B.J., 1985, Neutron-activation analysis of ground water around a chemical-waste landfill in the North Carolina Piedmont: abs., 1985 Triangle Conference on Environmental Technology, Raleigh, N.C.

LeGrand, H.E., 1954, Geology and ground water in the Statesville area, North Carolina: North Carolina Department of Conservation and Development Bulletin $68,68 \mathrm{p}$. 1958, Chemical character of water in the igneous and metamorphic rocks of North Carolina: Economic Geology, v. 53, no. 12, p. 179-189. 1967, Ground water of the Piedmont and Blue Ridge provinces in the southeastern states: U.S. Geological Survey Circular 538, 11 p. 1984, Ground water and its contamination in North Carolina with reference to waste management: $92 \mathrm{p}$.

LeGrand, H.E., and Mundorff, M.J., 1952, Geology and ground water in the Charlotte area, North Carolina: North Carolina Department of Conservation and Development Bulletin 63, $88 \mathrm{p}$.

Lutz, J.F., 1969, The movement and storage of water in North Carolina soils and the role of soil in determining water quality: Water Resources Research Institute of the University of North Carolina, no. 24, $45 \mathrm{p}$.

May, V.J., and Thomas, J.D., 1968, Geology and ground-water resources in the Raleigh area, North Carolina: North Carolina Department of Water and Air Resources Ground-Water Bulletin 15, 135 p. 
Mew, H.E., Jr., 1985, Ground water contamination and incident management in North Carolina: North Carolina Department of Natural Resources and Community Development, $17 \mathrm{p}$.

Mundorff, M.J., 1946, Ground water in the Halifax area, North Carolina: North Carolina Department of Conservation and Development Bulletin 51, $76 \mathrm{p}$.

1948, Ground water in the Greensboro area, North Carolina: North Carolina Department of Conservation and Development Bulletin 55, 108 p. Nacht, S.J., 1983, Monitoring sampling protocol considerations: Ground Water Monitoring Review, v. 3, no. 3, p. 23-29.

North Carolina Department of Human Resources, Division of Health Services, Solid and Hazardous Waste Management Branch, 1984, North Carolina 1983 annual report of hazardous waste generated, stored, treated, or disposed: North Carolina Solid and Hazardous Waste Management Branch Annual Report, $157 \mathrm{p}$.

Nutter, L.J., and Otton, E.G., 1969, Ground-water occurrence in the Maryland Piedmont: Maryland Geological Survey Report of Investigations no. $10,56 \mathrm{p}$.

Peace, R.R., Jr., and Link, D.R., 1971, Geology and ground-water resources of northwestern North Carolina: North Carolina Department of Water and Air Resources Ground-Water Bulletin 19, 135 p.

Pusey, R.D., 1960, Geology and ground water in the Goldsboro area, North Carolina: North Carolina Department of Water Resources Ground-Water Bulletin 2, $72 \mathrm{p}$.

Ragland, P.C., Hatcher, R.D., Jr., and Whittington, D., 1983, Juxtaposed Mesozoic diabase dike sets from the Carolinas, a preliminary assessment: Geology, v. 11, p. 394-399.

Richardson, C.A., 1982, Ground water in the Piedmont upland of central Maryland: U.S. Geological Survey Water-Supply Paper 2077, 42 p.

Russe11, G.S., Russe11, C.W., and Farrar, S.S., 1985, Alleghanian deformation and metamorphism in the eastern North Carolina Piedmont: Geological Society of America Bulletin, v. 96, p. 381-387.

Schipf, R.G., 1961, Geology and ground-water resources of the Fayetteville area: North Carolina Department of Water Resources Ground-Water Bulletin 3, $99 \mathrm{p}$.

Simmons, C.E., and Heath, R.C., 1979, Water-quality characteristics of forested and rural basins in North Carolina: U.S. Geological Survey Water-Supply Paper 2185-B, 33 p. 
Sokal, R.R., and Rohlf, F.J., 1969, Biometry: San Francisco, W.H. Freeman, $776 \mathrm{p}$.

Stewart, J.W., 1962, Water-yielding potential of weathered crystalline rocks at the Georgia Nuclear Laboratory: U.S. Geological Survey Professional Paper 450-B, 2 p.

Sumsion, C.T., and Laney, R.L., 1967, Geology and ground-water resources of the Morganton area: North Carolina Department of Water Resources Ground-Water Bulletin 12, 119 p.

Thornbury, W.D., 1954, Principals of geomorphology: New York, John Wiley and Sons, Inc., p. 135.

U.S. Soil Conservation Service, 1978, General soils map of North Carolina by Watershed: Raleigh, N.C., Soil Conservation Service and the North Carolina Department of Natural Resources and Community Development, 9 sheets.

Wehr, F., and Grover, L., III, 1985, Stratigraphy and tectonics of the Virginia-North Carolina Blue Ridge evolution of a late Proterozoicearly Paleozoic hinge line: Geological Society of America Bulletin, v. 96, p. $285-295$. 